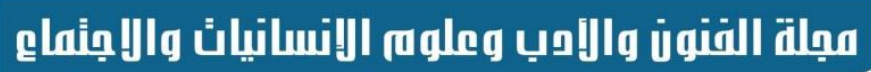 \\ Journal of Arts, Literature, Humanities \\ and Social Sciences
}

ISSN print: 2616- 3810

Volume 48

¿ALHSS

January 2020

www.jalhss.com

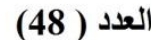

ISSN online: 2414 - 3383

\section{تحليل محثوى كتاب العلوم للصف السادس الابتدائي وفق معايير العلوم للجيل القادم NGSS}

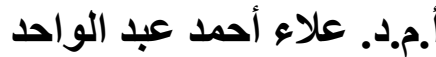

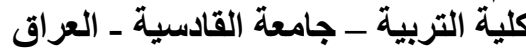 \\ alaa.ahmed@qu.edu.iq الايميل \\ علي فاضل سلمان \\ كلية التزبية - جامعة سلمان القادية ـ العراق \\ الايميل: ali12346@gmail.com
}

هدف البحث الحالي تحليل محتوى كتاب العلوم للصف السادس الابندائي المقرر من وزارة التربية العر اقية على وفق معايير العلوم للجيل القادم ال NGSS؛ ولتحقيق هذا الهدف اعد الباحثان قائمة بثلاث أبعاد هي: الممارسات العلمية، والهندسية، والمفاهيم الثاملة، والأفكار الأساسية، وتضمنت الأفكار الأساسية أربعة مجالات هي: علوم الحياة، و علوم الفيزياء، و علم الأرض، و الفضاء، و الهندسة، و التكنولوجيا، وسبعة و عشرون معيار ا، ومؤشر ات

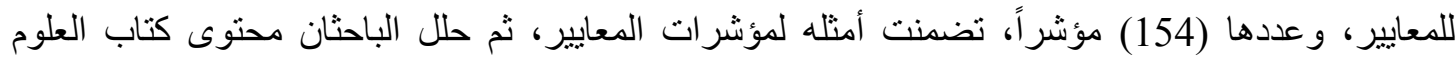
للسادس الابتدائي المقرر لعام الدراسي (2018-2019) في ضوء هذا المعيار، واعتمد الباحثان الفكرة الصريحة والضمنية في التحليل. وقد توصل الباحثان إلى أن كتاب العلوم للصف السادس الابتدائي قد حقق نسبة مقدارها (59.86\%) وتعد هذه النسبة منوسطة بالمقارنة بالنسب التي اعتمدها الباحثان، اذ حقق الكتاب (91)

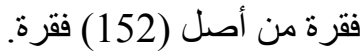

الكلمات المفتاحية: كتاب العلوم ، الساد الابتدائي، NGSS. 


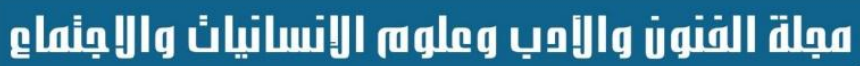

Journal of Arts, Literature, Humanities

and Social Sciences

ISSN print: 2616- 3810

Volume 48

¿ÁLHSS

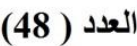

ISSN online: 2414 - 3383

January 2020

www.jalhss.com

يناير 2020

\section{Analyzing The Content of The Science Textbook for The Sixth Grade of Primary School According to Science Standards for The Next Generation NGSS}

\author{
Assist.Prof.Dr. Alaa Ahmed Abdulwahid \\ College of Education - Al-Qadisiya University - Iraq \\ Email: alaa.ahmed@qu.edu.iq
}

Ali Fadil Salman

College of Education - Al-Qadisiya University - Iraq

Email: ali12346@gmail.com

\begin{abstract}
The aim of the current research is to analyze the content of the science book for the sixth grade of primary education set by the Iraqi Ministry of Education according to the science standards for the next generation NGSS. To achieve this goal, the researchers prepared a list of three dimensions: scientific practices, engineering, comprehensive concepts, and basic ideas. The basic ideas included four areas They are: life sciences, physics, earth sciences, space, engineering, technology, twentyseven criteria, and indicators for standards, and there are (154) indicators, examples of which included criteria indicators, then the researchers analyzed the content of the science book for the sixth primary scheduled for the academic year (2018-2019) ) In light of this criterion, the researchers adopted the explicit and implicit idea in the analysis. The researchers found that the science textbook for the sixth grade of primary school has achieved a ratio of $(59.86 \%)$ and this ratio is average compared to the ratios approved by the researchers, as the book achieved (91) items out of (152) items.
\end{abstract}

Keywords: Science book, Sixth class, NGSS. 


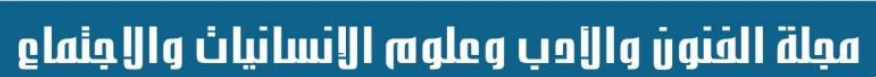 Journal of Arts, Literature, Humanities \\ and Social Sciences}

ISSN print: 2616- 3810

ISSN online: 2414 - 3383
Volume 48

January 2020

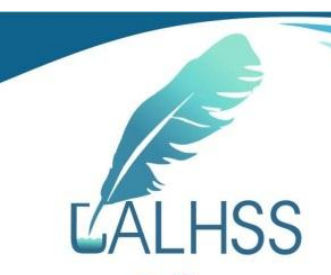

www.jalhss.com

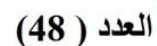

يناير 2020

الفصل الاول

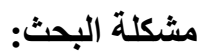

يمكن تحديد مشكلة البحث الحالي بحاجة مناهج العلوم للتطوير، و التحديث المستمر استجابة لمتطلبات التقدام

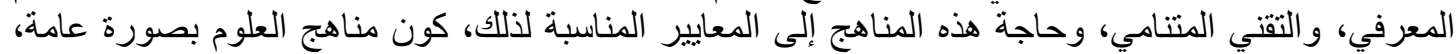

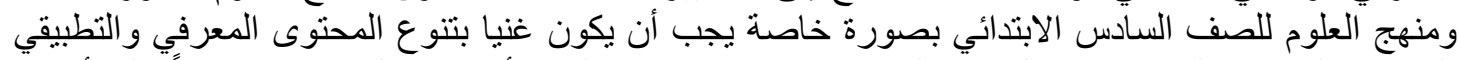

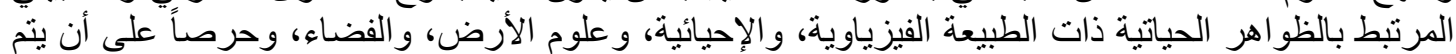

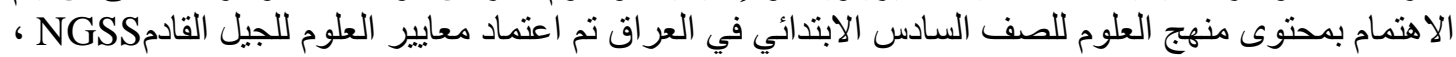

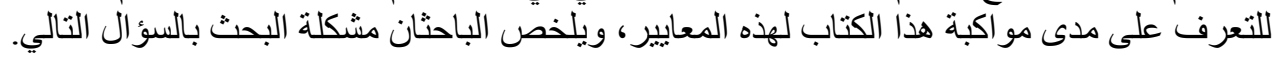

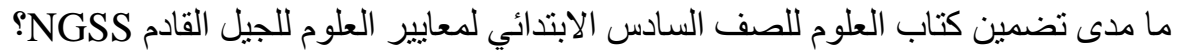

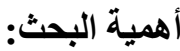

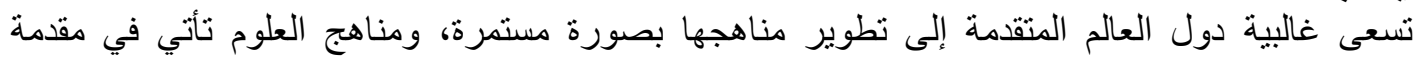

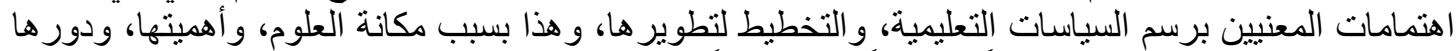

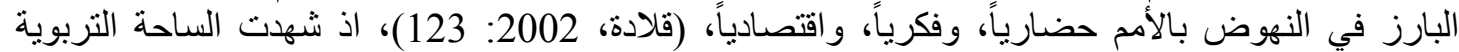

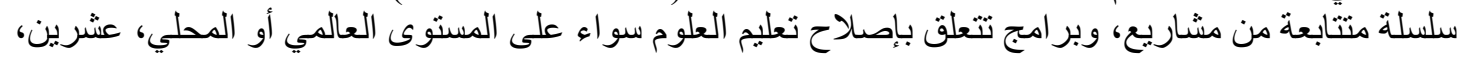

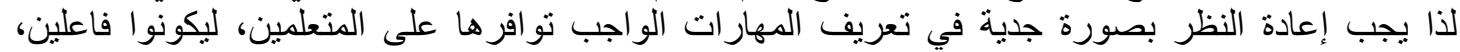

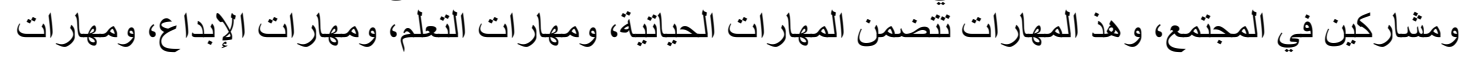

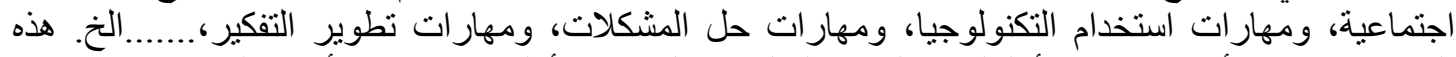

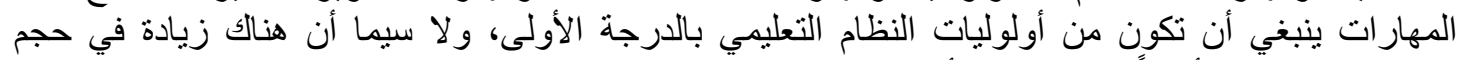

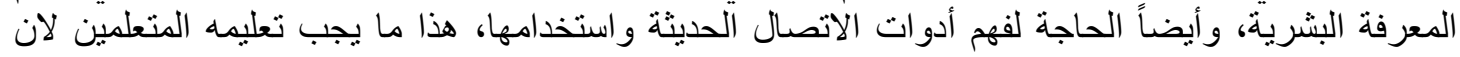

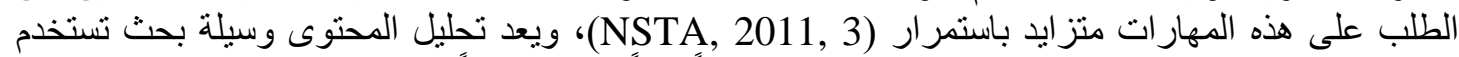

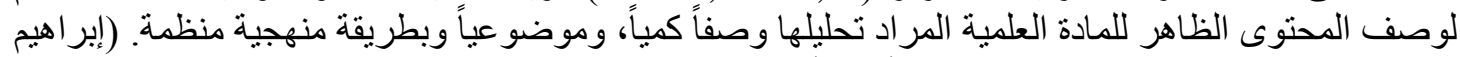

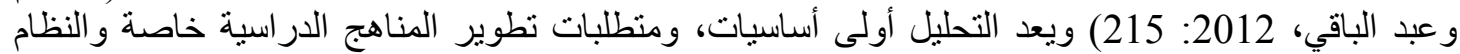

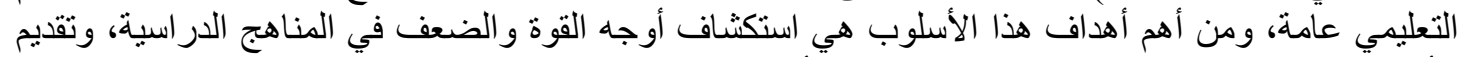

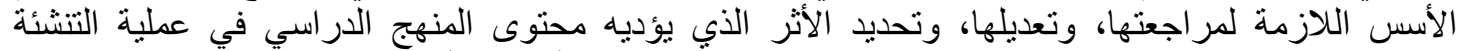

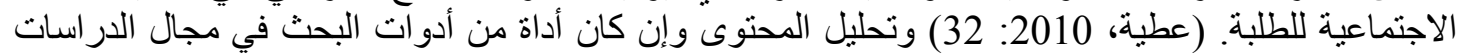

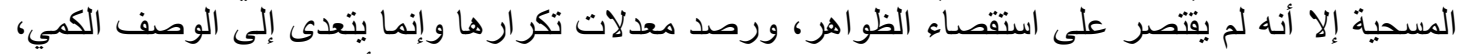

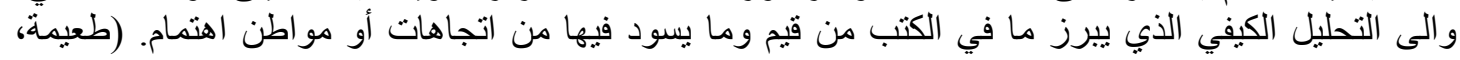
2008: 2008

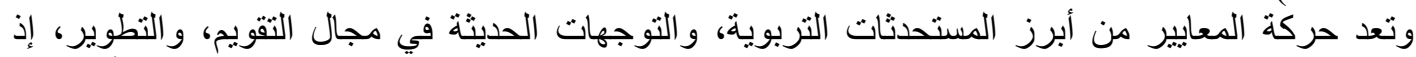

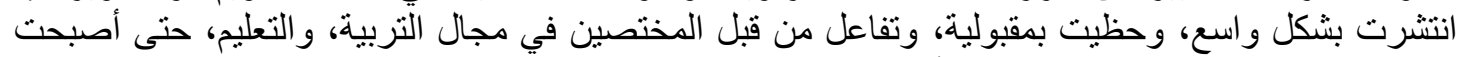

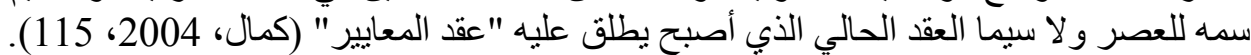

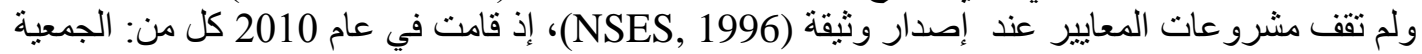

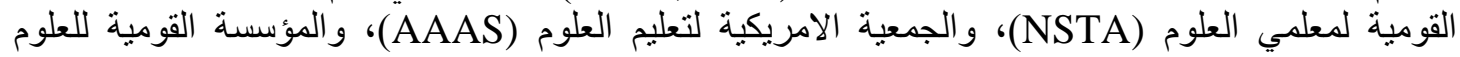

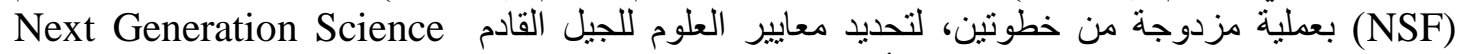

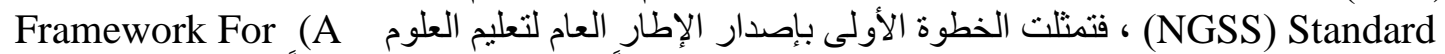
K-12 Education, 2011)

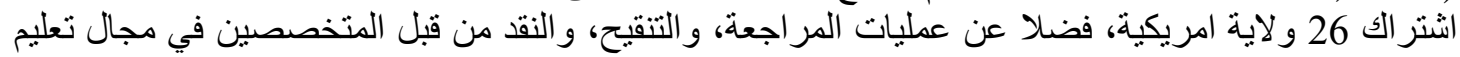

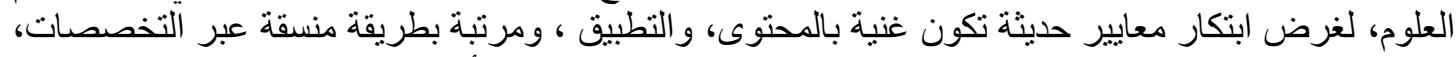

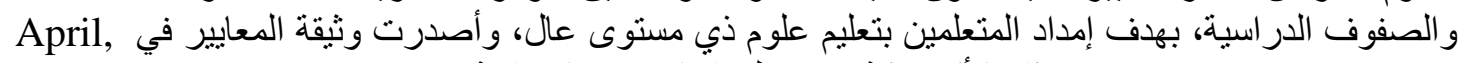

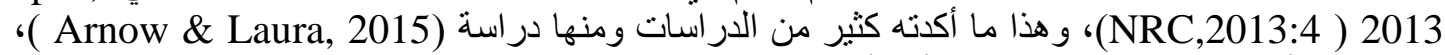

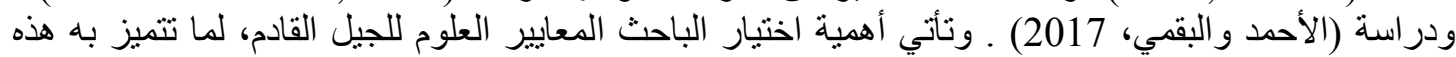
المعايير عن المعايير السابقة بمميزات عن معايير العلوم السابقة في ثلاث نقاط أساسية: 


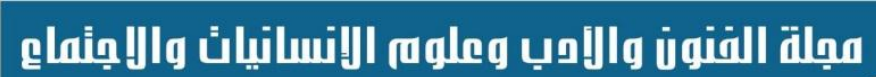 Journal of Arts, Literature, Humanities \\ and Social Sciences}

ISSN print: 2616- 3810

ISSN online: 2414 - 3383
Volume 48

January 2020
¿ÁLHSS www.jalhss.com

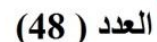

يناير 2020

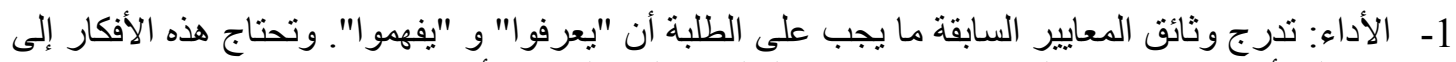

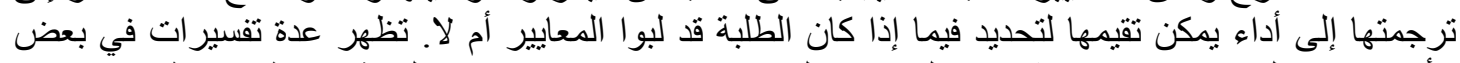

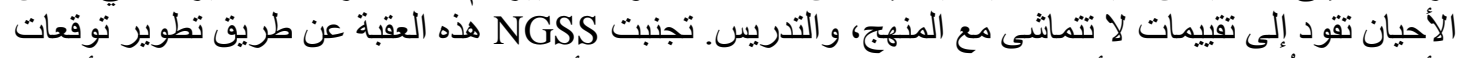

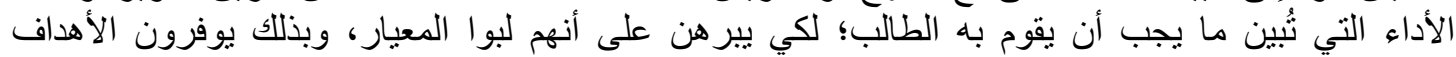

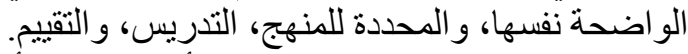
2- المرتكزات: يتضمن كل توقع للأداء جميع الأبعاد الثناثة من هيكلية العملـ ممارسة العلوم أو الهندسة، الأفكار الرئيسة، و المفاهيم الثناملة.

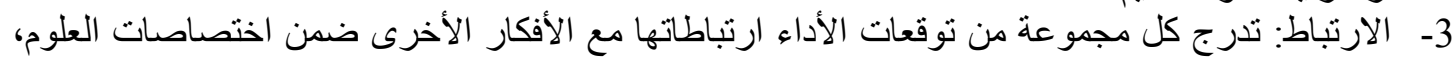

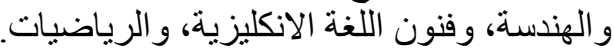

(NGSS, 2013 B, 1)

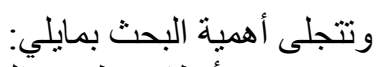

1- نوجيه أُنظار مطورو المناهج في وزارة التربية العر اقية إلى الاهتمام بمعايير العلوم للجيل القادم عند تطوير

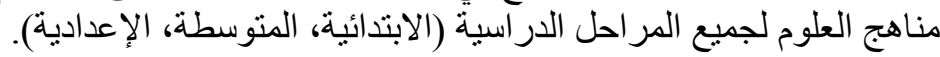

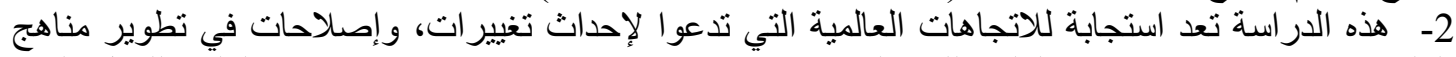
العلوم بصورة عامه ومناهج العلوم للمرحلة الابتدائية بصورة خاصة خاصة في ضوء لإن معايير العلوم للجيل القادم .NGSS 3- يقام الباحثان قائمة معيارًا بأبعاده، ومعاييره، ومؤشراته، وأمثلته لمعايير العلوم للجيل القادم في محتوى

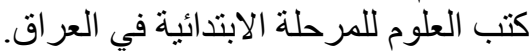

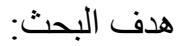
تحليل كتاب العلوم للصف السادس الابتدائي وفق معايير العلوم للجيل القادم NGSS.

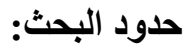

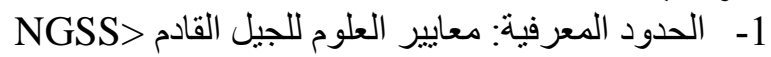
2- 20 - الحدود الزمانية: 2018-2019.

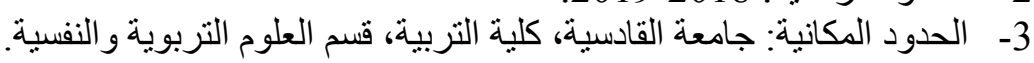
تحديد المصطلحات:

1 - معايير العلوم للجيل القادم Next Generation Science Standers (NGSS) عرفها (Reiser,2013) معايير وضعت على أساس الحاجة لجعل تعليم العلوم ذي معنى، وفاعلية للمتعلمين

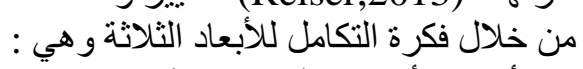

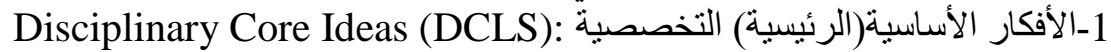

2- المفاهيم الثاملة (المشتركة) : Crosscutting Concepts (CCS)

3-الممارسات العلمية والهندسية Science and Engineering Practices (SEPS)

(Reiser,2013:30)

$$
\text { يتبنى الباحثان تعريف (Reiser,2013) نظرياً }
$$

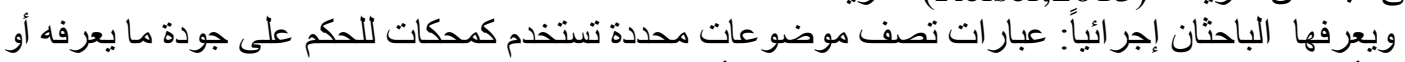

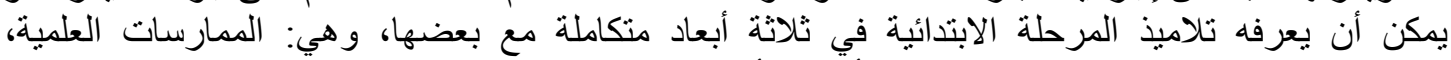
و الهندية، و المفاهيم الثاملة (المشتركة)، و الأفكار الأساسية.

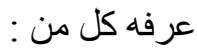

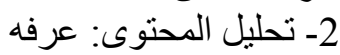
* (صابر وميرفت، 2002) بأنه اسلوب في البحث لوصف المحتوى الظاهر وصفاً موضو عياً منظماً وكمياً. (صابر وميرفت: 2002: 158)

* (داوود، 2011) بأنه أسلوب في البحث يستخدم لوصف المحتوى الظاهر وصفاً موضو عياً ومنطقياً وكمياً في (2002:

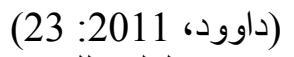
ضو و وحدة التحليل المستخدمة.

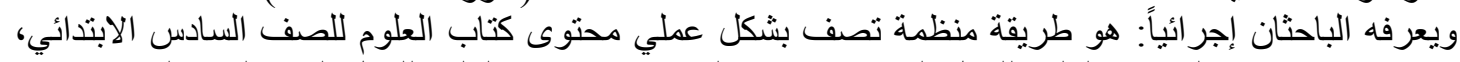

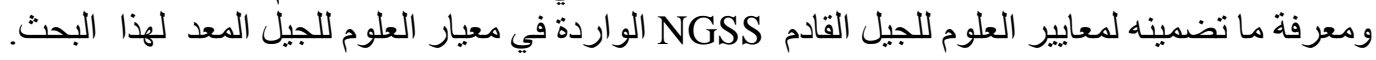




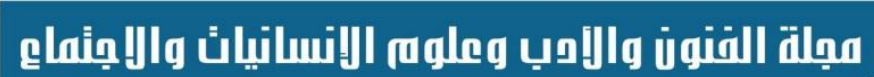 Journal of Arts, Literature, Humanities \\ and Social Sciences}

ISSN print: 2616- 3810

ISSN online: 2414 - 3383

\author{
Volume 48 \\ January 2020

\section{الفصل الثاني \\ خلفية نظرية ودر استات سابقة}

LALHSS

www.jalhss.com

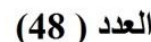

يناير 2020

اولاًَ- ابعاد معايير العلوم للجيل القادم: معادئ

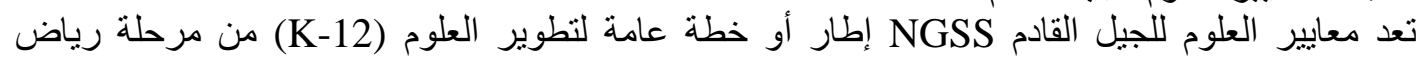

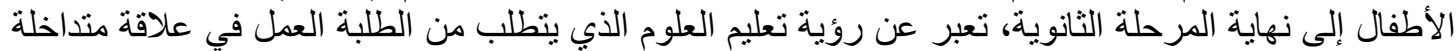

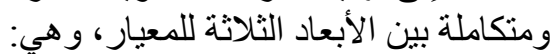

1- الممارسات العلمية و الهندسية Science and Engineering Practices (SEPS)

2- الأفكار الأساسية(المحورية التخصصية) Disciplinary Core Ideas (DCLS)

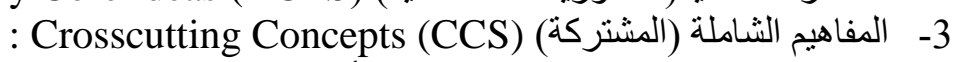
وتتصف معايير العلوم للجيل القادم NGSS بأنها:

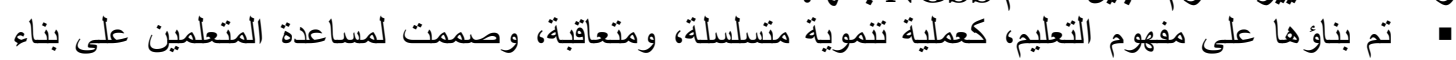

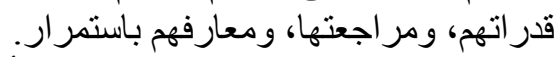

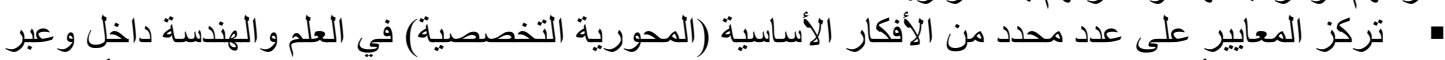
التخصصات، من أجل تجنب العدد الكبير للمواضيع، وتوفير الأبير فرصة للطلبة و المعلمين على استكثاف أي فكرة بمزيد من العمق.

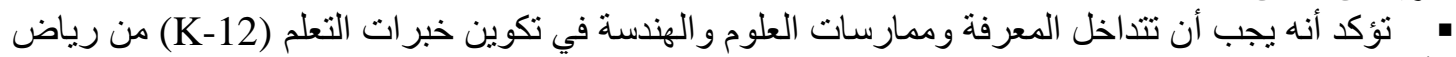

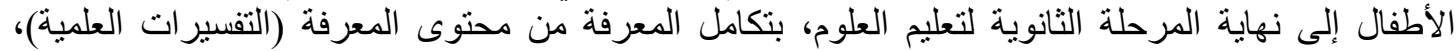
ـالبعد الأول لـ (NGSS,2013E:1)

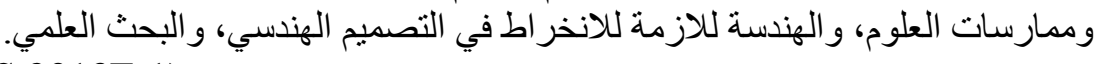

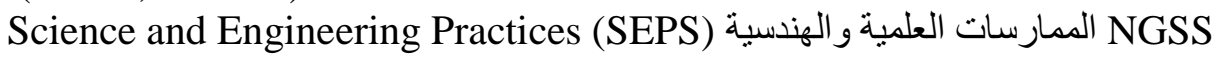

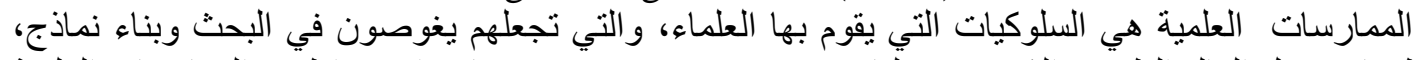

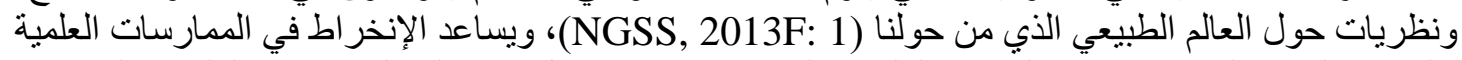

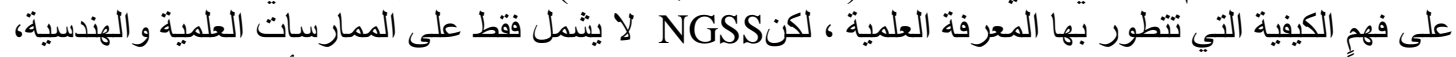

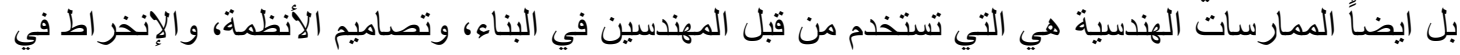

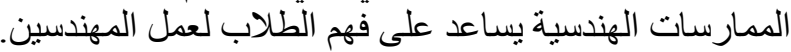
وحددت الممارسات في ثمان ممارسات علمية، و هندسية، ومن الضروري تعلم هذه الممارسات لجميع

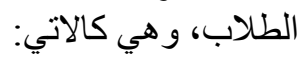

(NGSS, 2013M: 12)

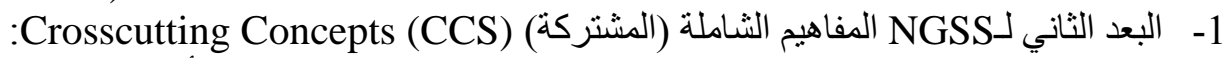

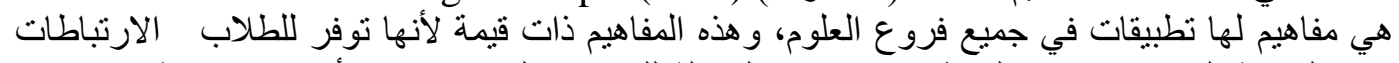

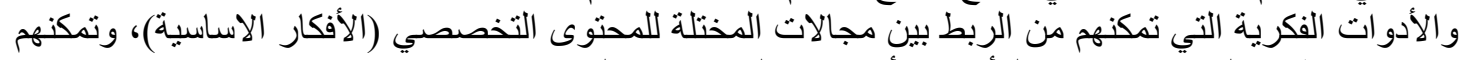

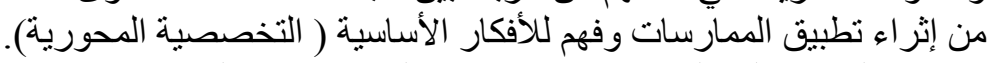
وحددت المفاهيم الثاملة في سبعة مفاهيم شاملة الطانة، وهي كما يلي:

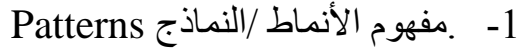

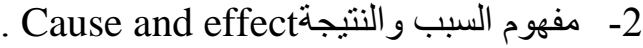
3-3 - مفهوم المقياس، و النسبة، و الكمية. Scale, Proportion, and Quantity 4- - مفهوم النظم ونماذج النظم:Systems and system models

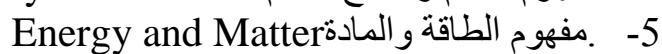
Structure and Function مفهوم التركيب والوظيفة

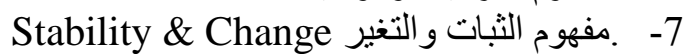
البعد الثالث لـ NGSS الأفكار الأساسية(الرئيسية) التخصصية (DCLS (Disciplinary Core Ideas (DCL : 


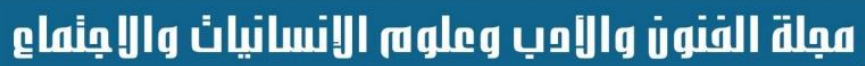 Journal of Arts, Literature, Humanities \\ and Social Sciences}

ISSN print: 2616- 3810

Volume 48

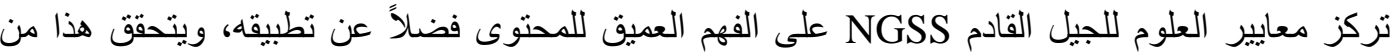

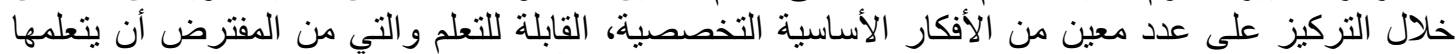

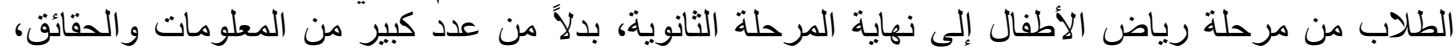
(NGSS, 2013 N: 3)

وتتصف الأفكار الأساسية التخصصية كما يذكرها الإطار العام لتعليم العلوم، بأنها:

توفر أداة مهمة لفهم واستكثاف المشكلات المات المعقدة وحلها.

• قابليتها للتعلم و التعليم لصفوف والتهنة ومستويات متعددة، وتزداد بالعمق، والتطور والتعقيد بزيادة المستويات (الابتدائية، المتوسطة، الاعطم الاعدادية).

• ترتبط بخبرات الطلاب الحياتية، واتهماماته الاجتماعية، والثخصية، والتي تتطلب معرفة علمية وتكنلوجية. لها أهمية واسعة، وشاملة، عبر المجالات العلوم و الهندسة. (NRC, 2013: 30)

$$
\begin{aligned}
& \text { وتقسم الأفكار الأساسية إلى: } \\
& \text { 1- } \\
& \text { 2- - علم الفيزياء. } \\
& \text { 3- علم الأرض و الفضاء. }
\end{aligned}
$$

\begin{tabular}{|c|c|c|c|c|c|c|c|}
\hline 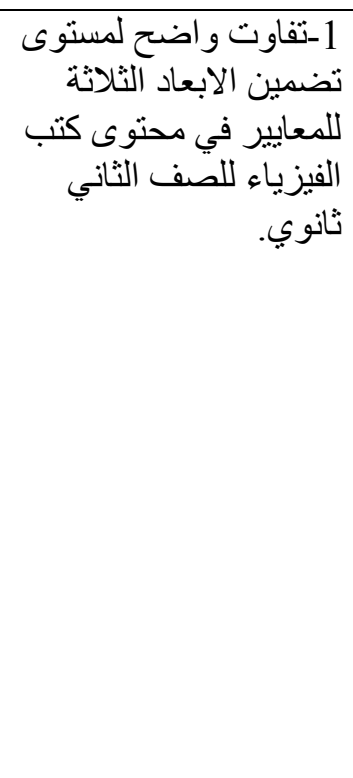 & التهنث & الداة تحليل & لب البحث بتمثنل & السعربية المملية & 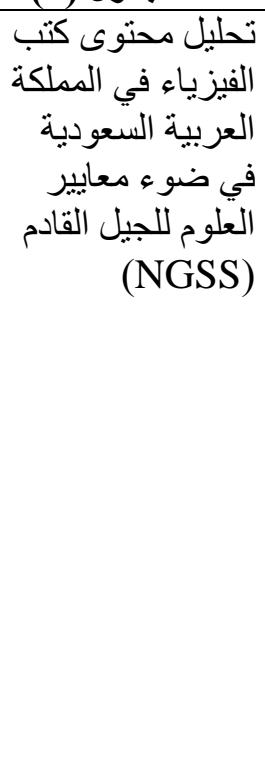 & والإحمد، & 1 \\
\hline 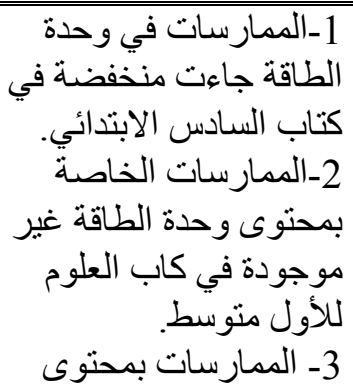 & التهنث & الداة تحليل & البحث كتب الصنو & السعربية المعلة & 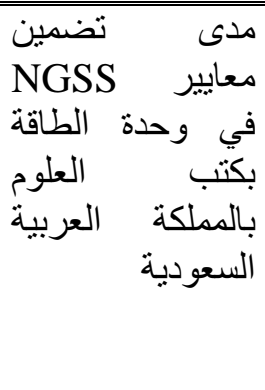 & الجبر، & 2 \\
\hline
\end{tabular}

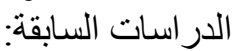

تناول الباحثان اثثين من الدراسات السابقة التي تتعلق بمعايير العلوم للجيل القادم التيات جدول (1) الدراسات التي تناولت التحليل ومعايير العلوم للجيل القادم التيل 


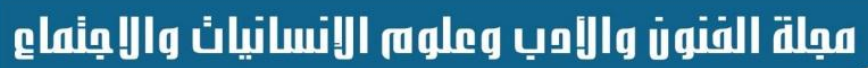 Journal of Arts, Literature, Humanities \\ and Social Sciences}

ISSN print: 2616- 3810

ISSN online: 2414 - 3383

Volume 48

\begin{tabular}{|c|c|}
\hline 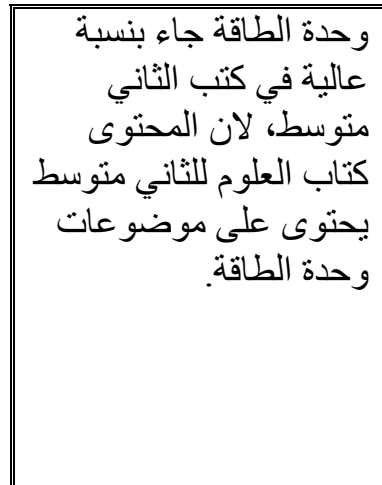 & 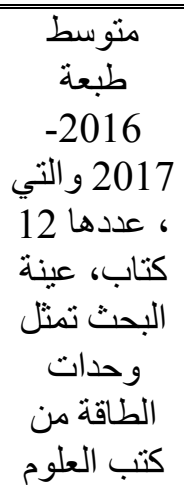 \\
\hline
\end{tabular}

\section{الفصل الثالث \\ إجراءات البحث}

اعنمد الباحثان منهج البحث الوصفي من أجل تحليل كتاب العلوم للصف السادس الابتدائي لما لهذا المنهج من

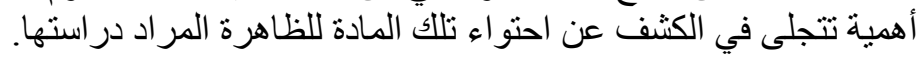

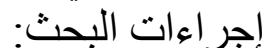

1. مجتمع البحث: يتمثل بكتاب العلوم للصف السادس الابتدائي وبو اقع (252) صفحة. 2. عينة البحث: تتمثل بكتاب العلوم للصف السادس الابتدائي وبواقع (247) صفحة بعد استبعاد صفحات الفهارس، ومقدمة الكتاب.

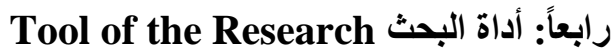

تم بناء قائمة معايير تحليل كتاب العلوم للصف الساد الإبتدائي في ضوء معايير NGSS، وذللك من خلال

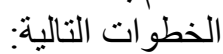
1-تحديد الهدف من بناء قائمة معايير:

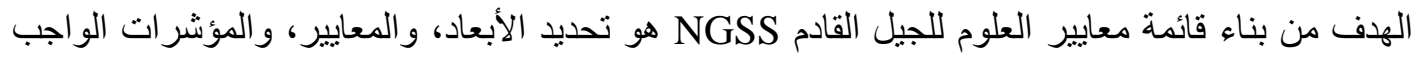

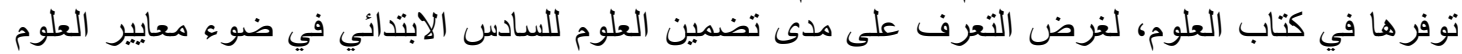

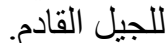

2-إعداد قائمة بمعايير العلوم بصورتها الاولية:

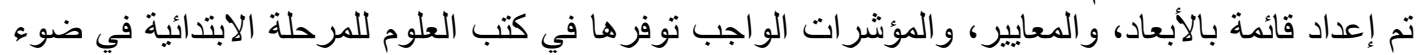

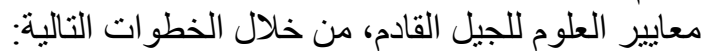

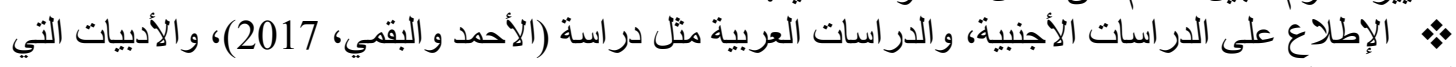

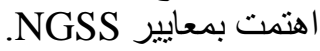

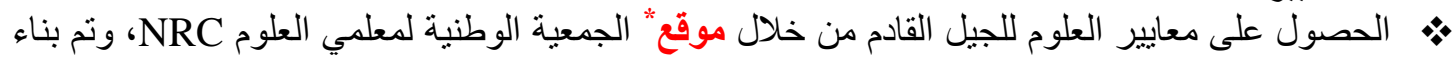

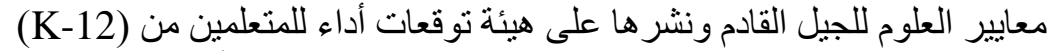

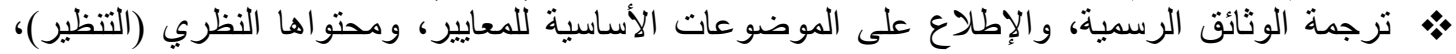

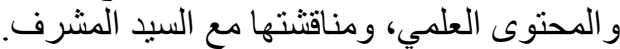
و أخذ الباحثان في كتابة قائمة معايير العلوم للجيل القادم بأبعادها، ومعايير ها، ومؤشر اتها بعض من المحددات.

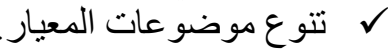

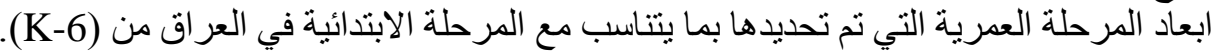

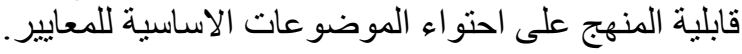




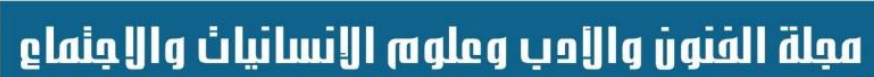 Journal of Arts, Literature, Humanities \\ and Social Sciences}

\section{ISSN print: 2616- 3810}

ISSN online: 2414 - 3383
Volume 48

January 2020
LALHSS www.jalhss.com

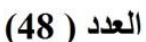

يناير 2020

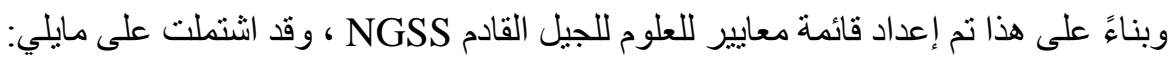

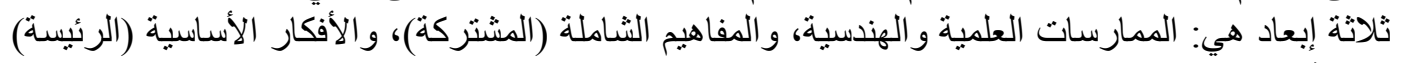

التخصصية.

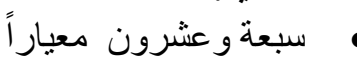

• أربعة مجالات هي: علوم الحباة، و علم الأرض و الفضاء، والعلوم الفيزيائية، وتطبيقات العلوم و الهندسة

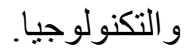

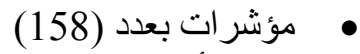

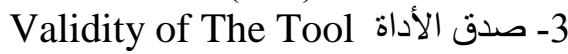

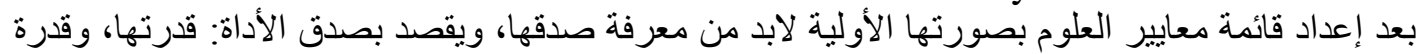

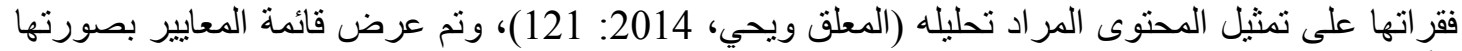

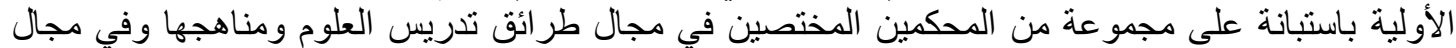

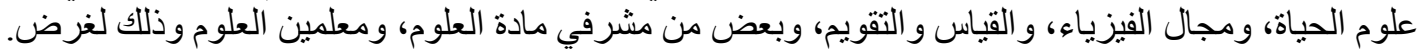

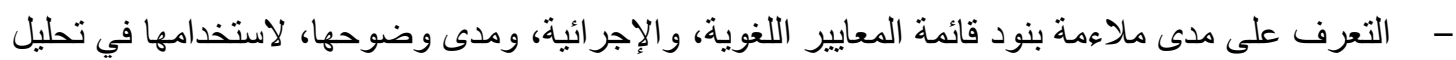
كتاب العلوم للصف السادس الابندائي .

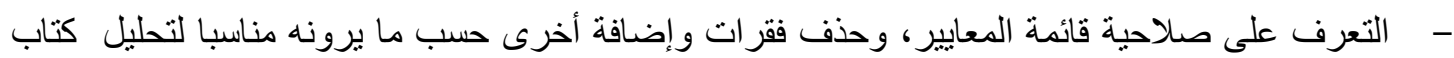
العلوم للسادس الابتدائي.

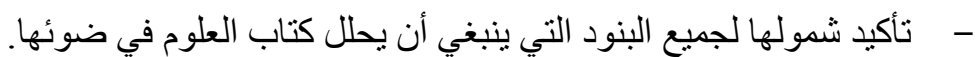

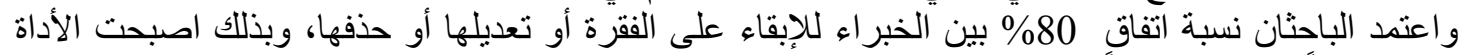

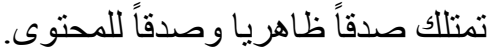

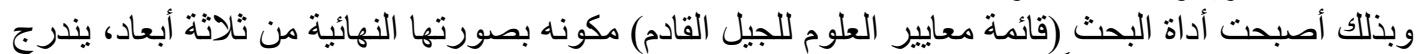

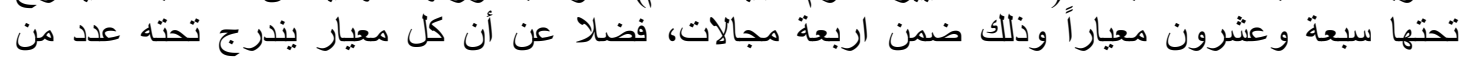

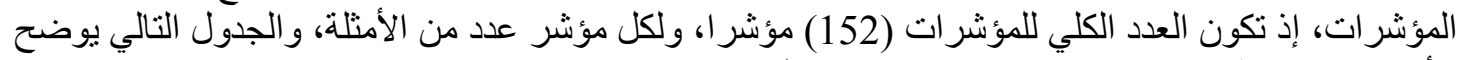

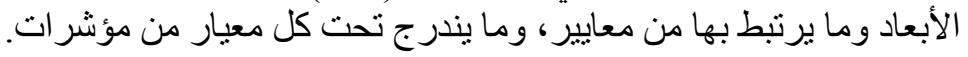

جدول (2) مواصفات قائمة معايير العلوم للجيل القادم

\begin{tabular}{|c|c|c|c|c|}
\hline المئوية للبعد & 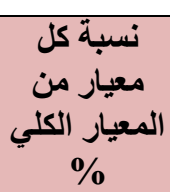 & 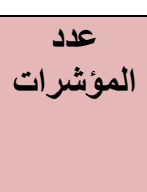 & المعايير & الابعاد \\
\hline \multirow{7}{*}{$\% 23.68$} & $\% 3.28$ & 5 & 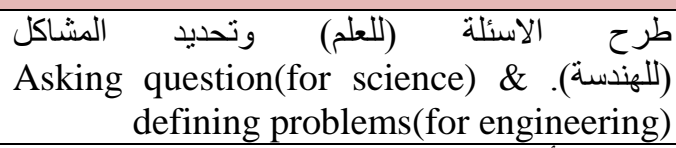 & \multirow{7}{*}{$\begin{array}{r}\text { Science and ) الممارسات العلمية و الهندسية } \\
\text { Engineering Practices (SEPS }\end{array}$} \\
\hline & $\% 3.28$ & 5 & 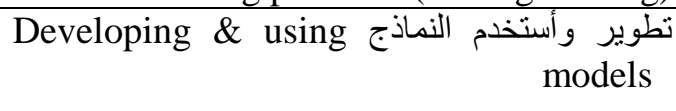 & \\
\hline & $\% 1.97$ & 3 & $\begin{array}{r}\text { planning \& carrying تخطيط وتنفيذ الاستقصاءات } \\
\text { out investigation }\end{array}$ & \\
\hline & $\% 3.28$ & 5 & Analyzing \& interpreting تحليل وتفسير البيانات & \\
\hline & $\% 2.63$ & 4 & 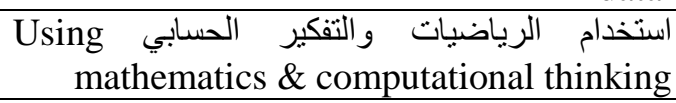 & \\
\hline & $\% 2.63$ & 4 & 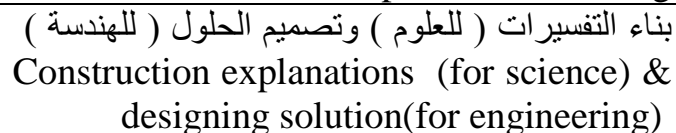 & \\
\hline & $\% 3.94$ & 6 & الانخر اط في الحجج من الادلة. Engaging in & \\
\hline
\end{tabular}




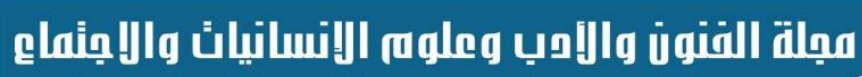

Journal of Arts, Literature, Humanities

and Social Sciences

ISSN print: 2616- 3810

ISSN online: 2414 - 3383

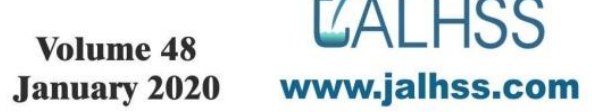

(48) (48)

يناير 2020

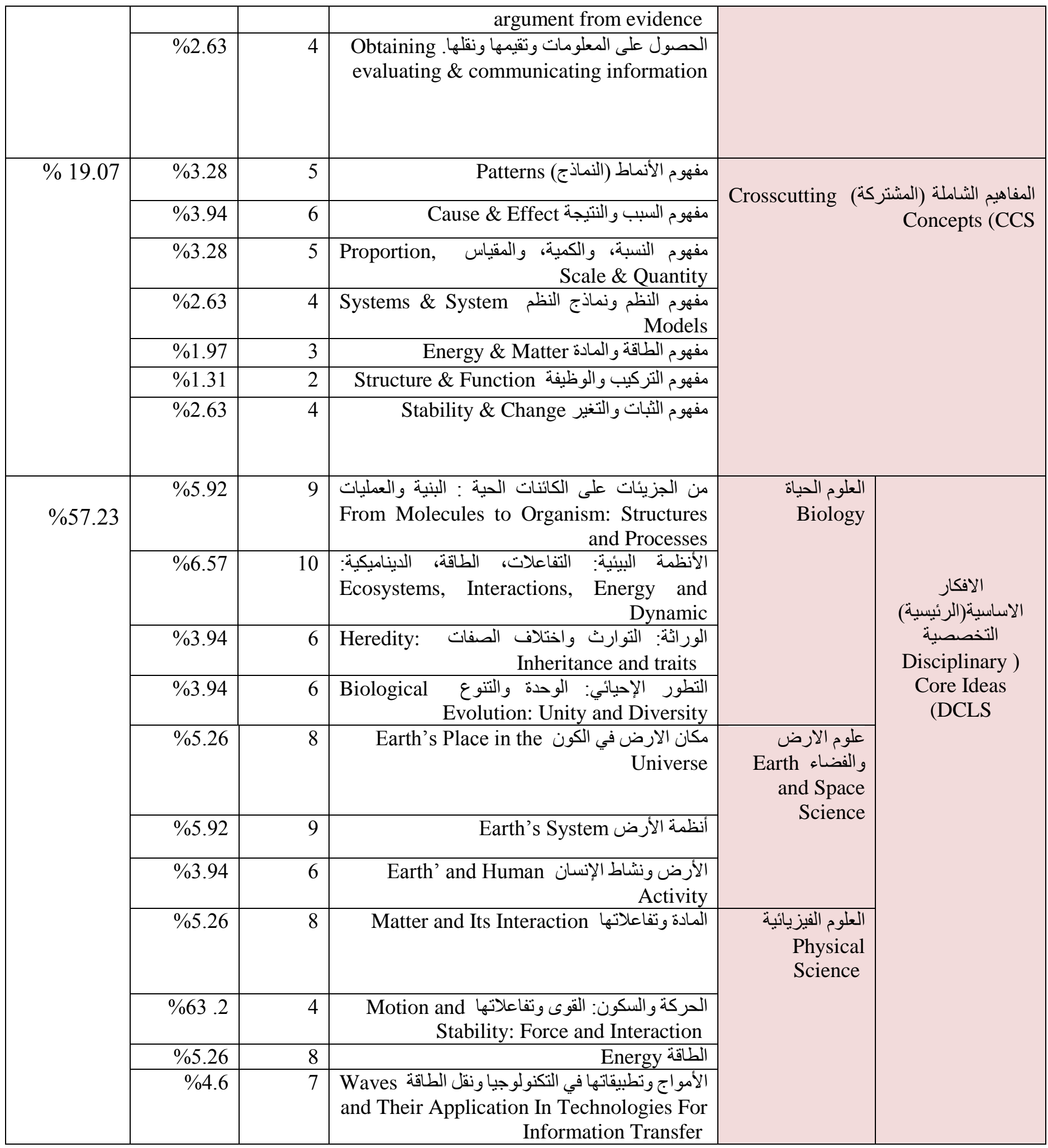




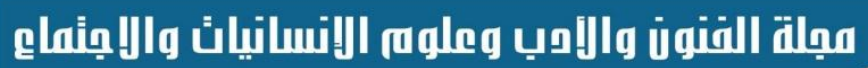 Journal of Arts, Literature, Humanities \\ and Social Sciences}

ISSN print: 2616- 3810

ISSN online: 2414 - 3383

Volume 48 January 2020
LALHSS www.jalhss.com

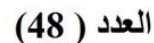

يناير 2020

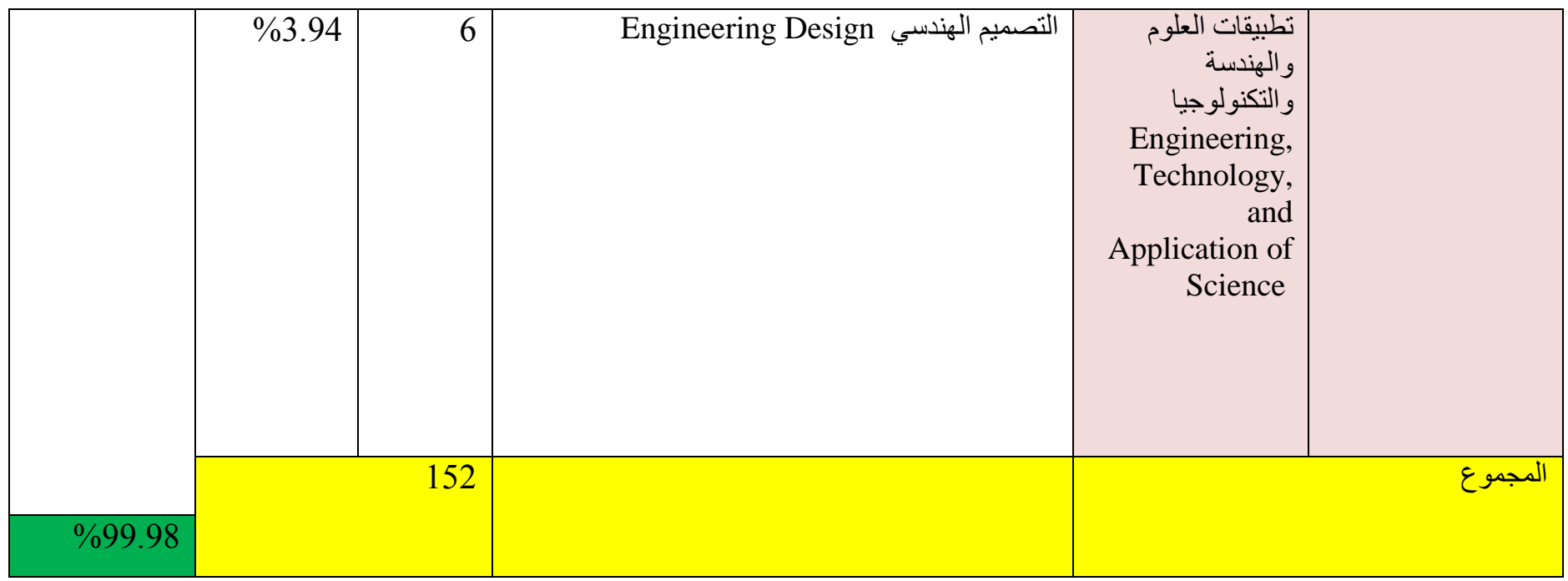

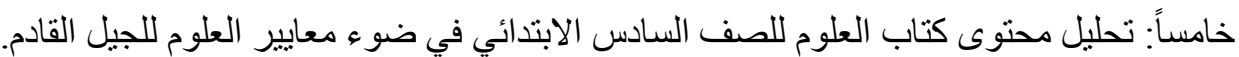

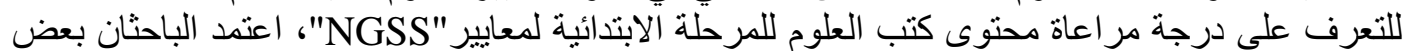

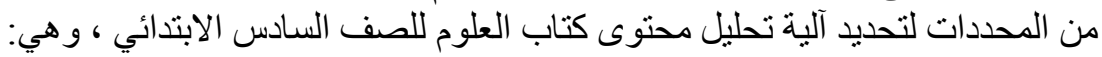
1 الحديد الهدف من التحليل Limitation the aim analysis استهدف الباحثان في هذه العملية تحديد درجة مر اعاة محتوى كتاب العلوم للصف السادس الابندائي لمعايير NGSS

2- تحديد وحدات التحليل Limitation Units of analysis تعني وحدات المحتوى التي يمكن أن تخضع للعد او القياس بغية التوصل إلى دلالات أو قراءات تساعد في

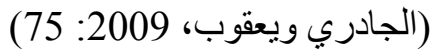
تفسير النتائج و واستخدم الباحث وحدات التحليل، التالية:

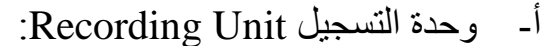

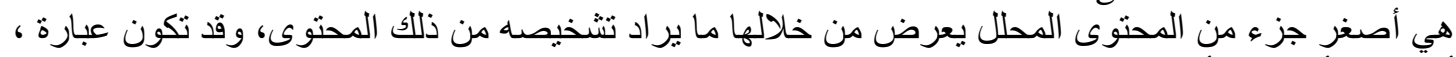

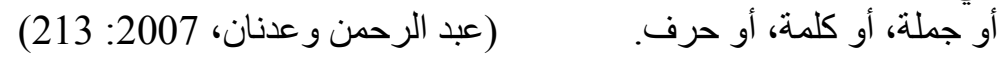

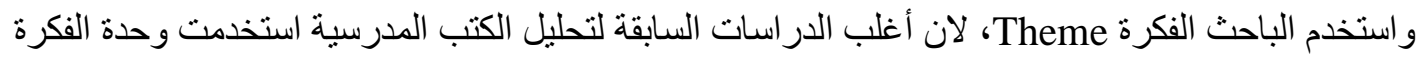

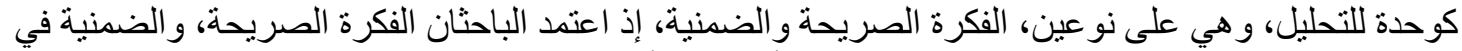

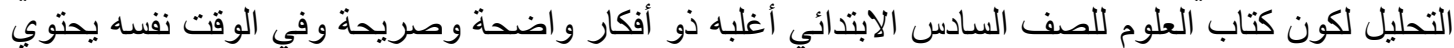
على أفكار ضمنية قد تحقق المعيار.

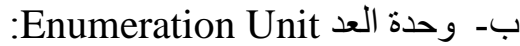

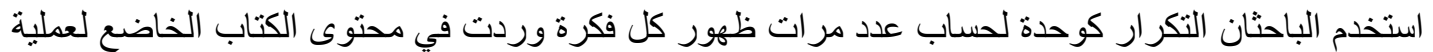

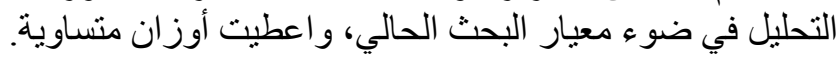

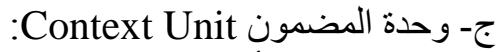
هي الفقرة أو مجموع الفقرات أو الموضوع بصورة كاملة، الذي نقوم بدراسته بهدف التعرف على على الفي

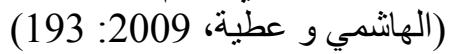
وحدة التسجيل، و والعد.

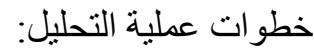

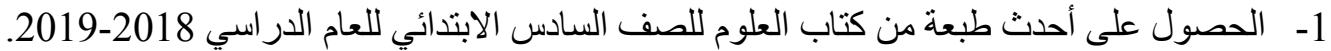

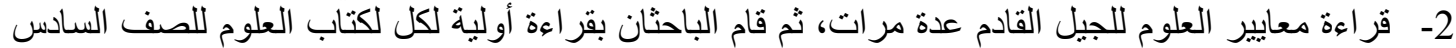
الابتدائي، لتحديد الفكرة التي تقع ضمن معايير العلوم. 


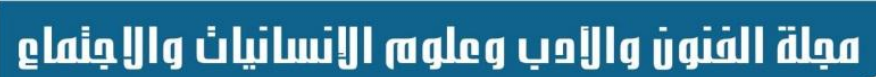 Journal of Arts, Literature, Humanities \\ and Social Sciences}

ISSN print: 2616- 3810

ISSN online: 2414 - 3383
Volume 48

January 2020
LALHSS www.jalhss.com

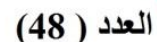

يناير 2020

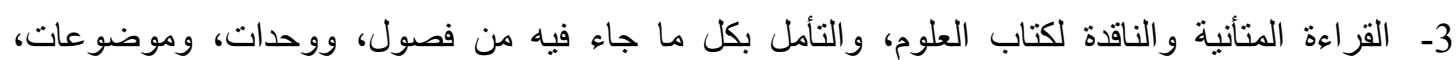

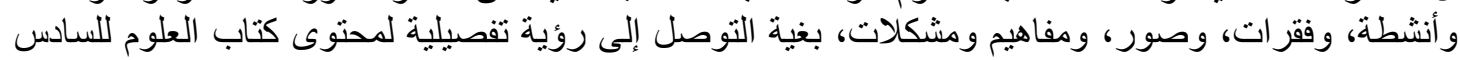

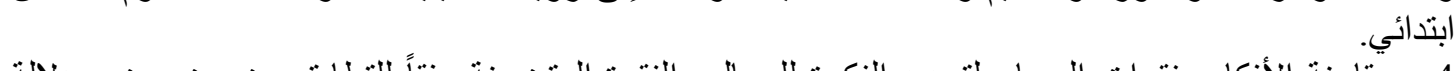
4- مقارنة الأفكار بفقرات المعيار لتحديد الفكرة للمجال و الفقرة المتضمنة وفقاً للتطابق بين مضمون، ودلالة الفكرة مع مضمون فقرة الاكتر المعيار.

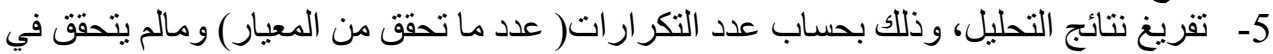

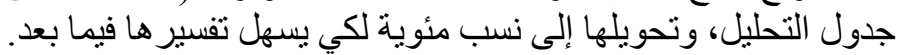

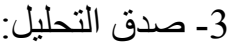

قام الباحثان باختبار صدق التحليل، وذلك من خلال الاستعانة بخبيرين* بطر ائق تدريس العلوم، وينم ذلك

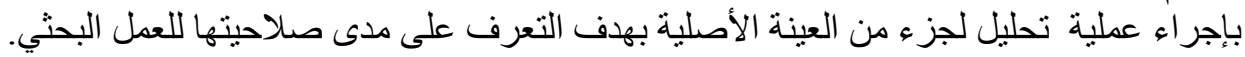

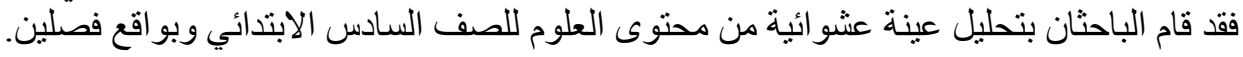

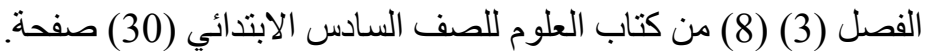

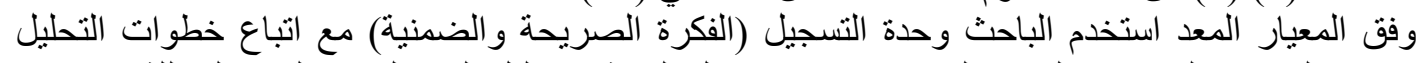

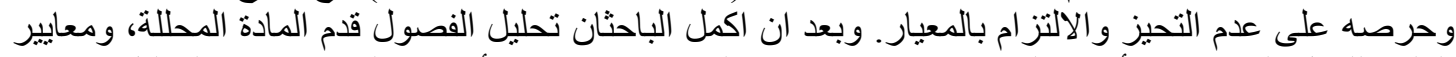

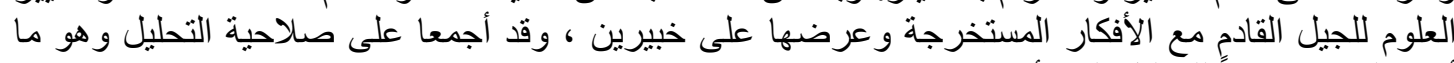

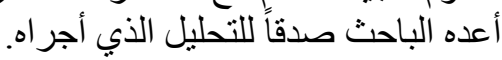

\section{4- ثقدات التحليل: (Scott, 1969:187)}

و الثبات يتأثر بمهارة المحلل وخبرته في التحليل ووضوح البيانات المحللة، فضلاً عن تأثره بوضوح قو اعد (Kerilnger, 1975: 129)

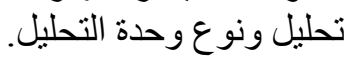
لذا فاستخدم الباحثان طريقتنين لحساب الثبات، لكي تكون عملية التحليل تتمتع بالموضوعية والابنعاد عن آراء

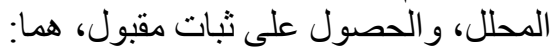

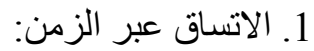

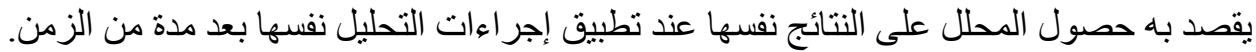

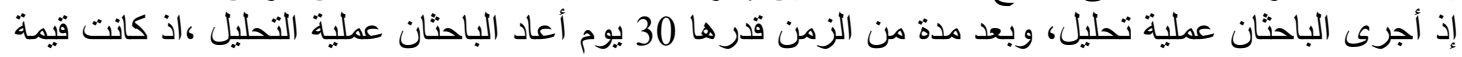

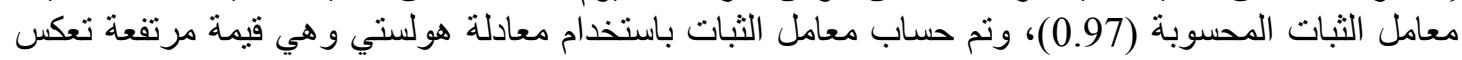

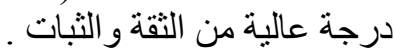
2. 2 الثبات (الاتساق بين المحلاتين):

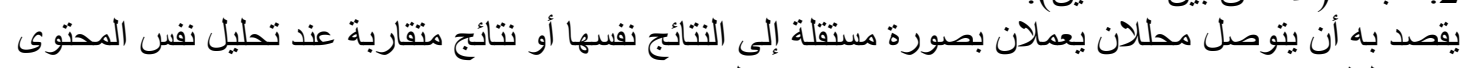

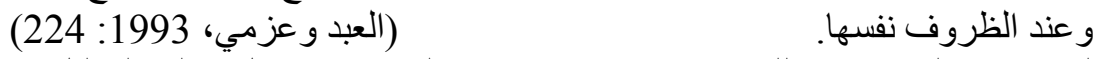

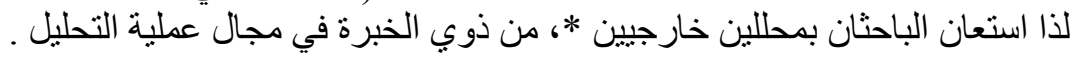

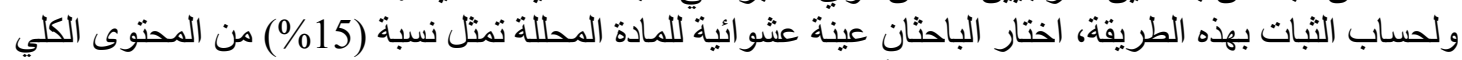

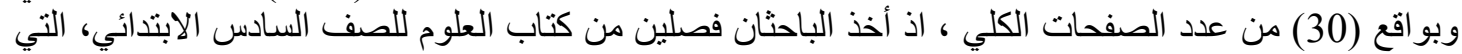

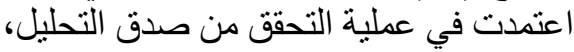

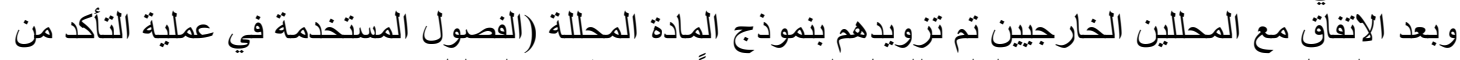

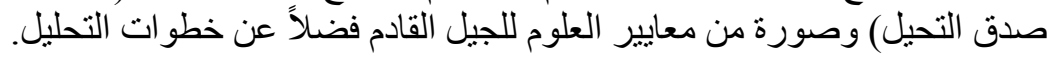

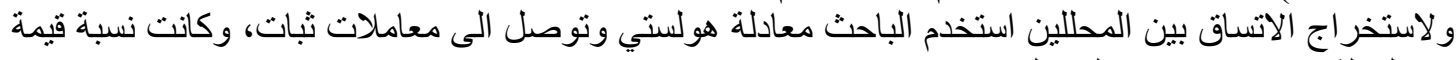

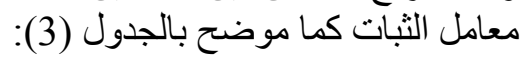




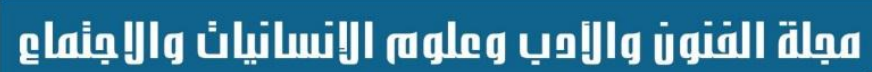 Journal of Arts, Literature, Humanities \\ and Social Sciences}

ISSN print: 2616- 3810

Volume 48

ISSN online: 2414 - 3383

\section{January 2020}

\begin{tabular}{|c|c|c|}
\hline نسبة معامل الثبات & الثبات بين & نوع الثبات \\
\hline$\% 0.97$ & الباحث ونفسه بعد 30 يوم & عبر الزمن \\
\hline$\% 0.91$ & الباحث و المحلل الاول & \multirow{3}{*}{ الثبات عبر المحللين } \\
\hline$\% 0.90$ & الباحث و المحلل الثاني & \\
\hline$\% 0.90$ & المحلل الاول و المحلل الثاني & \\
\hline
\end{tabular}

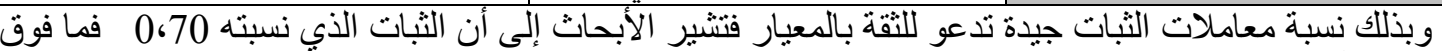

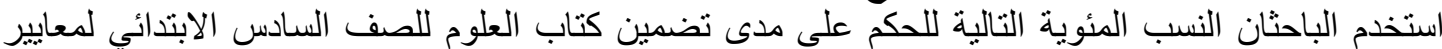

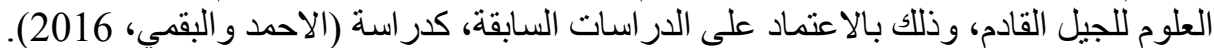

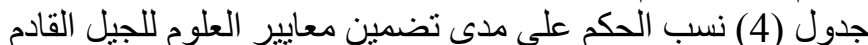

\begin{tabular}{|c|c|c|}
\hline مستوى التضمين & النسبة المئوية & ت \\
\hline منخفض جدا & من 0 إلى اقل من 25\% & 1 \\
\hline 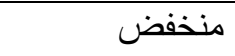 & من25\% إلى اقل من 50\% & 2 \\
\hline متوسط & من 50\% إلى اقل من 75\% & 3 \\
\hline 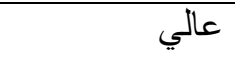 & من 75\% إلى اقل من 100\% & 4 \\
\hline
\end{tabular}

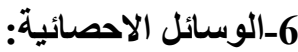
استخدم الباحث معادلة هولستي الأفي

$R=\frac{2 C C 1+2}{C 1+C 2}$

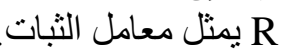
2CC1+2 عدد الإجابات المتفق عليها من قبل المحللين. C1 تمثل عدد إجابات المحلل الأول. C2 - يمثل عدد إجابات المحلل الثناني.

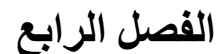 \\ عرض النتائج ومناقشته الرغا}

يتضمن هذا الفصل عرض للنتائج المتعلقة بهدف البحث، وتفسيرها، والاستتناجات التي توصل اليها الباحثان، والتوصيات و المقترحات المناسبة للبحث الحت الحالي: هدف البحث هو التعرف على مدى تضمين محتوى كتاب العلوم للصف السادس الابتدائي لمعايير العلوم للجيل القادم 1- نتائج تحليل كتاب العلوم للصف السادس الابتدائي

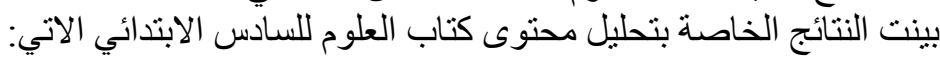




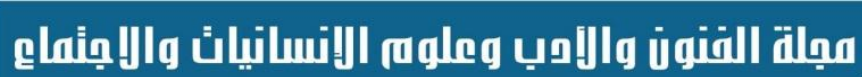

Journal of Arts, Literature, Humanities

and Social Sciences

ISSN print: 2616- 3810

ISSN online: 2414 - 3383
Volume 48

January 2020
¿ALHSS

(48) - العدد (4020)

يناير 2020 ينس

جدول (5) التكرارات والنسب المئوية لفقرات معيار معايير العلوم للجيل القادم في كتاب العلوم للصف السادس الابتدائي

\begin{tabular}{|c|c|c|c|c|c|c|c|c|c|c|c|c|c|c|c|c|c|}
\hline \multirow{2}{*}{ 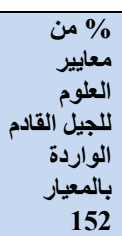 } & \multirow{2}{*}{ نبلة } & \multirow[t]{2}{*}{$\%$} & \multirow{2}{*}{ تجمرارا } & \multicolumn{10}{|c|}{ تكرارات المؤشرات } & \multirow[t]{2}{*}{ 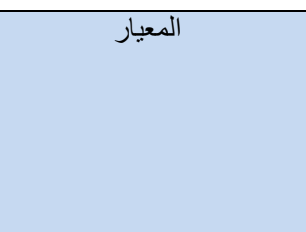 } & \multirow[t]{2}{*}{$ت$} & \multicolumn{2}{|c|}{ البعد } \\
\hline & & & & م10 & $\frac{9_{p}}{p}$ & 88 & $7_{p}$ & be & $55^{p}$ & 4 & $\overline{3 s}$ & 28 & $\overline{18}$ & & & & \\
\hline \multirow{27}{*}{$\begin{array}{l}\text { \%59.86 } \\
\%\end{array}$} & \multirow{8}{*}{$\% 40.66$} & $\% 7.2$ & 74 & & & & & & 10 & 14 & 14 & 25 & 11 & طشيكلات الاسئلة وتحليد & 1 & \multirow{8}{*}{\multicolumn{2}{|c|}{ العلمية والهمارسية }} \\
\hline & & $\% 1.65$ & 17 & & & & & & 1 & 3 & 3 & 2 & 8 & تطوير واستخذام النماذج & 2 & & \\
\hline & & $\% 6.62$ & 68 & & & & & & & & 14 & 17 & 55 & تخطيط وتنفيذ الاستقصاءات & 3 & & \\
\hline & & $\% 3.01$ & 31 & & & & & & 10 & 3 & 5 & 7 & 6 & تحليل وتفسير البيانات & 4 & & \\
\hline & & $\% 3.01$ & 31 & & & & & & & 9 & 5 & 6 & 11 & الرياضيات والتفكير الحسابي & 5 & & \\
\hline & & $\% 4.67$ & 48 & & & & & & & 5 & 12 & 10 & 21 & الحلول التفسيرات وتصميم & 6 & & \\
\hline & & $\% 3,6$ & 37 & & & & & 1 & $\mathbf{0}$ & $\mathbf{0}$ & 9 & 14 & 13 & الادلة الاطر في الحجج من & 7 & & \\
\hline & & $\% 10.9$ & 112 & & & & & & & 29 & 35 & 25 & 23 & وتقيمهول ولقلى المعلومات & 8 & & \\
\hline & \multirow{7}{*}{$\% 47.38$} & $\% 9.54$ & 98 & & & & & & 23 & 23 & 18 & 12 & 22 & الانماط / النماذج & 1 & \multirow{7}{*}{\multicolumn{2}{|c|}{ ثانيا: المفاهيم الثشاملة }} \\
\hline & & $\% 14.5$ & 149 & & & & & 14 & 36 & 15 & 44 & 15 & 25 & السبب والنتيجة & 2 & & \\
\hline & & $\% 5.55$ & 57 & & & & & & 15 & 10 & 4 & 9 & 19 & النسبة والكمية والمقياس & 3 & & \\
\hline & & $\% 7.1$ & 73 & & & & & & & 18 & 22 & 16 & 17 & النظم ونماذج النظم & 4 & & \\
\hline & & $\% 0.77$ & 8 & & & & & & & & 3 & 4 & 1 & الطاقة والمادة & 5 & & \\
\hline & & $\% 66.03$ & 62 & & & & & & & & & 32 & 30 & التركيب والوظيفة & 6 & & \\
\hline & & $\% 3.89$ & 40 & & & & & & & 11 & 6 & 5 & 18 & الثبات والتغير & 7 & & \\
\hline & \multirow{12}{*}{$\% 11.83$} & $\% 2.62$ & 27 & & $\mathbf{0}$ & $\mathbf{0}$ & 6 & 4 & $\mathbf{0}$ & 1 & $\mathbf{0}$ & 16 & $\mathbf{0}$ & الحية: الجزينيةت والىعلى الكانتات & 1 & \multirow{4}{*}{ 1 الحياة علوم } & الالأكار \\
\hline & & $\% 0.87$ & 9 & $\mathbf{0}$ & $\mathbf{0}$ & $\mathbf{0}$ & $\mathbf{0}$ & $\mathbf{0}$ & 1 & 1 & $\mathbf{0}$ & 3 & 4 & الأطاقة، الإنبئئيكية: التفاعلات، & 2 & & \\
\hline & & $\mathbf{0}$ & $\mathbf{0}$ & & & & & $\mathbf{0}$ & $\mathbf{0}$ & $\mathbf{0}$ & $\mathbf{0}$ & $\mathbf{0}$ & $\mathbf{0}$ & الصفاتة: التوارث واختلاف & 3 & & \\
\hline & & $\mathbf{0}$ & $\mathbf{0}$ & & & & & $\mathbf{0}$ & $\mathbf{0}$ & $\mathbf{0}$ & $\mathbf{0}$ & $\mathbf{0}$ & $\mathbf{0}$ & والتنوع الاحيائي: الوحدة & 4 & & \\
\hline & & $\% 0.97$ & 10 & & & $\mathbf{0}$ & 1 & 5 & 3 & $\mathbf{0}$ & $\mathbf{0}$ & $\mathbf{0}$ & 1 & مكان الارض في الكون & 1 & \multirow{3}{*}{ 2ألارضاء } & \\
\hline & & $\% 0.77$ & 8 & & $\mathbf{0}$ & $\mathbf{0}$ & $\mathbf{0}$ & 7 & $\mathbf{0}$ & $\mathbf{0}$ & $\mathbf{0}$ & 1 & $\mathbf{0}$ & انظمة الارض & 2 & & \\
\hline & & $\mathbf{0}$ & $\mathbf{0}$ & & & & & $\mathbf{0}$ & $\mathbf{0}$ & $\mathbf{0}$ & $\mathbf{0}$ & $\mathbf{0}$ & $\mathbf{0}$ & الارض والنشاط الانسان & 3 & & \\
\hline & & $\% 2.33$ & 24 & & & 3 & 12 & $\mathbf{0}$ & $\mathbf{0}$ & 2 & 4 & $\mathbf{0}$ & 3 & المادة وتفاعلاتها & 1 & \multirow{4}{*}{ | الفيزياء } & \\
\hline & & $\% 0.19$ & 2 & & & & & & & 2 & 0 & 0 & 0 & وتفاعلاتها والسكون: القوى & 2 & & \\
\hline & & $\% 1.85$ & 19 & & & 8 & 2 & 5 & 0 & 4 & 0 & 0 & 0 & الطاقة & 3 & & \\
\hline & & $\% 0.97$ & 10 & & & & 2 & 0 & 0 & 4 & 2 & 0 & 2 & التكولولوجيا ونقيقل الطقاقة في & 4 & & \\
\hline & & $\% 1.26$ & 13 & & & & & 0 & 0 & 0 & 0 & 0 & 13 & التصميم الهندسي & 1 & تطبيقات & \\
\hline
\end{tabular}




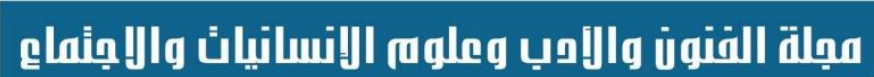 Journal of Arts, Literature, Humanities \\ and Social Sciences}

ISSN print: 2616- 3810

ISSN online: 2414 - 3383

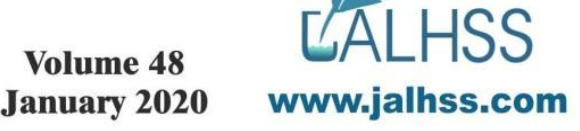

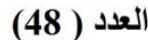

نياير 2020

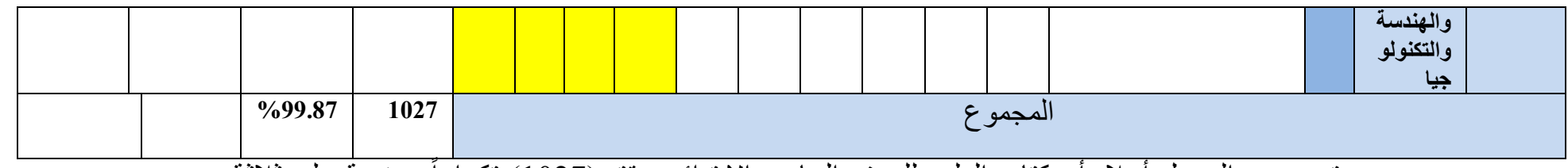

يتضح من الجدول أعلاه أن كتاب العلوم للصف السادس الابتدائي حقق (1027) نكر ارأ موزعة على ثلى ثلاثة

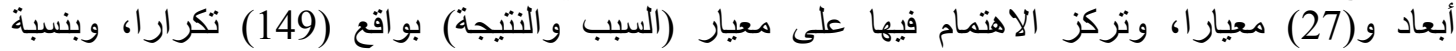

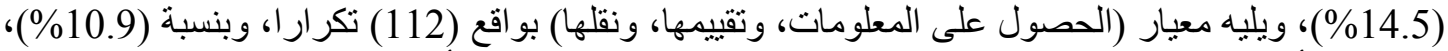

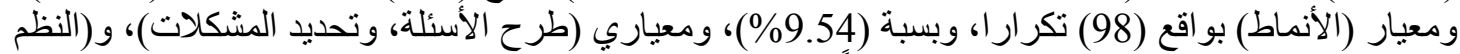

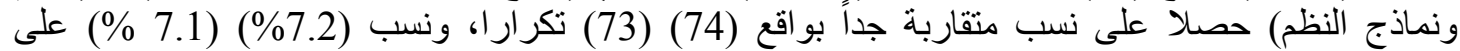

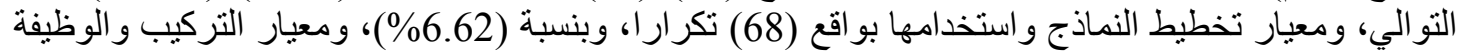

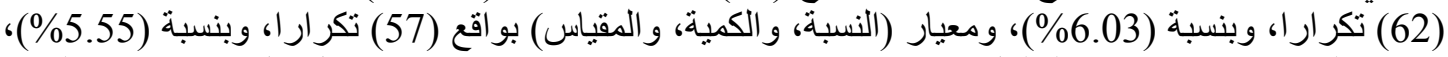

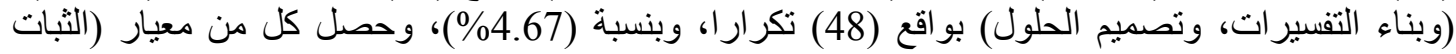

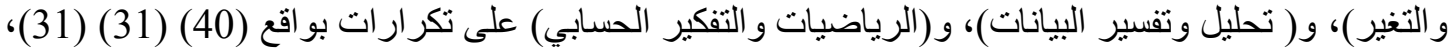

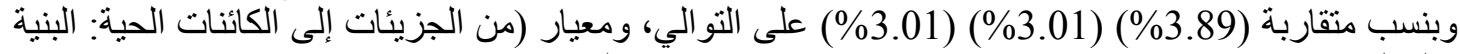

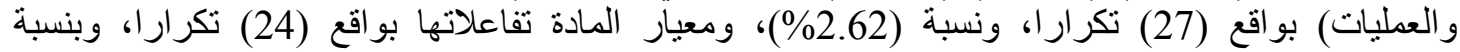

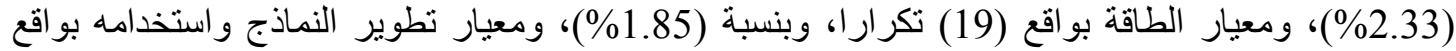

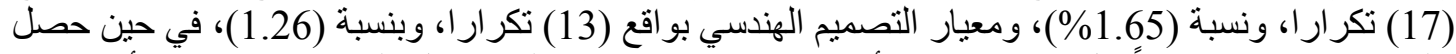

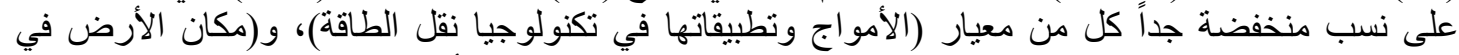

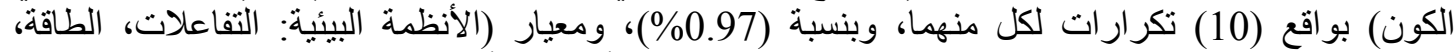

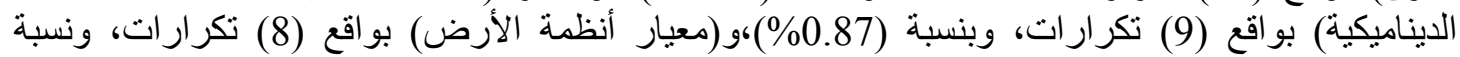

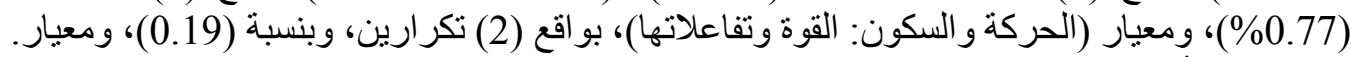

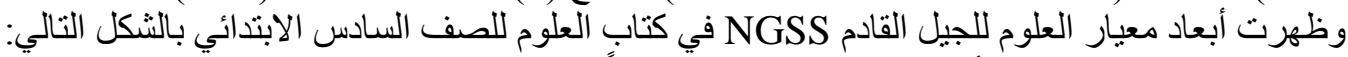

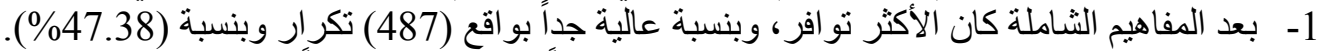

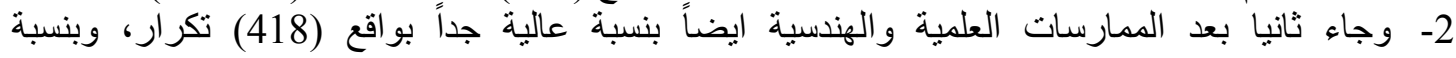
. $1 \% 40.66)$

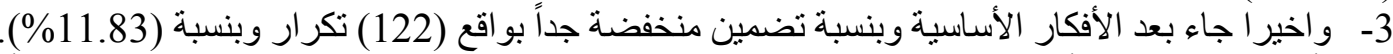

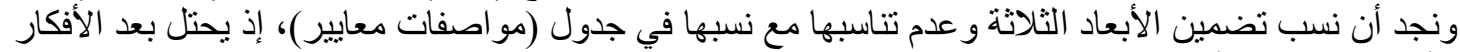

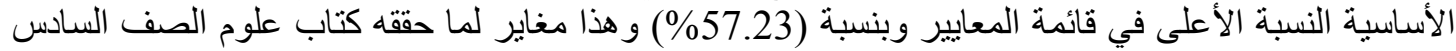

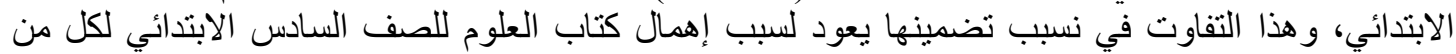

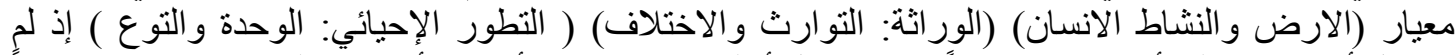

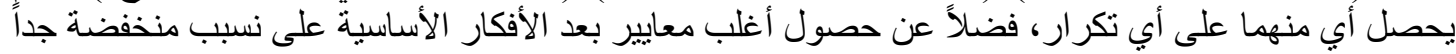

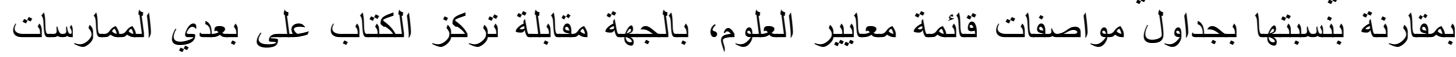

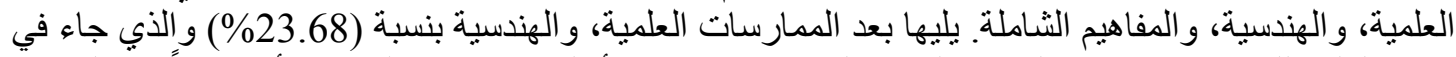

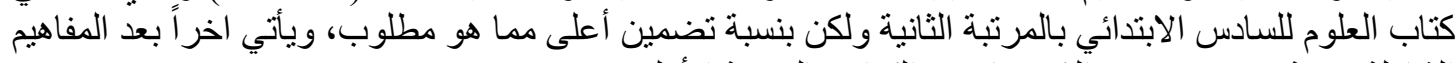

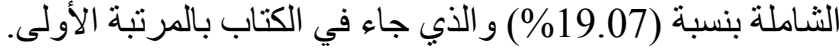
الجوانب غير المتحققة في كتاب العلوم للصف الصف السادس الابتدائي:

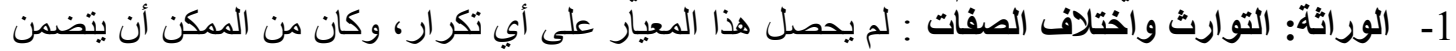

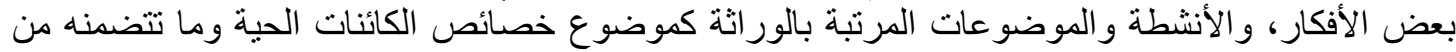

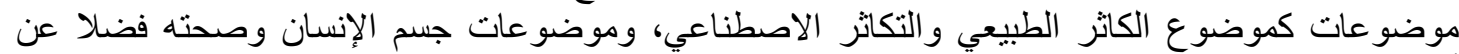

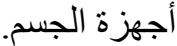

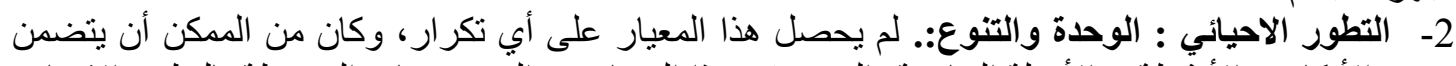

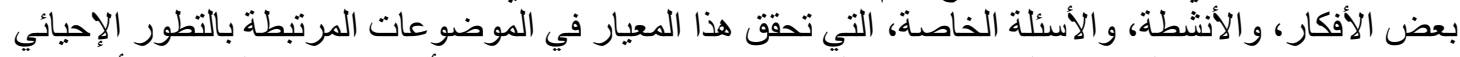

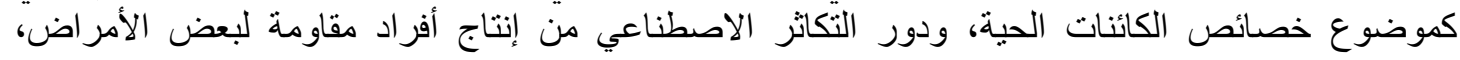




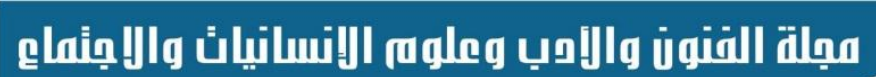 Journal of Arts, Literature, Humanities \\ and Social Sciences}

ISSN print: 2616- 3810

ISSN online: 2414 - 3383
Volume 48

January 2020
LALHSS www.jalhss.com

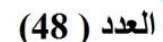

يناير 2020

والآفات ـ وكذللك موضوعات أثر حركة الصفائح الأرضية ، وما هو أثر الزلازل والبراكين في تغيير بيئة

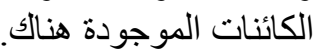

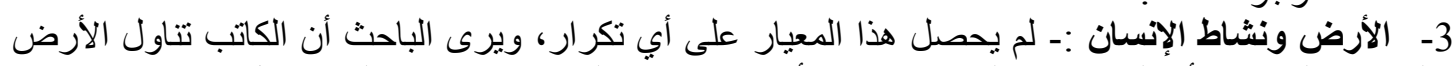

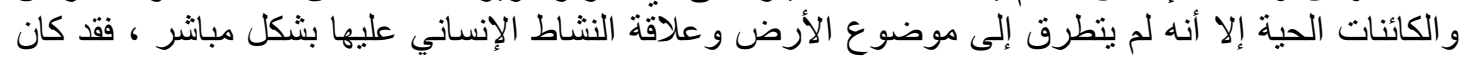

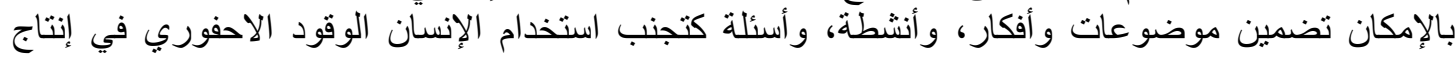

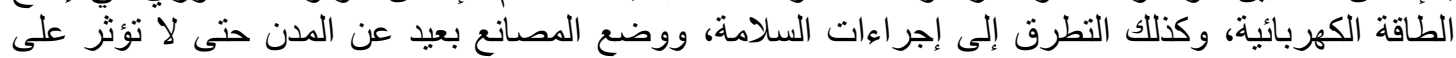

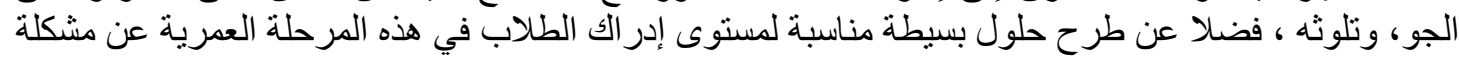

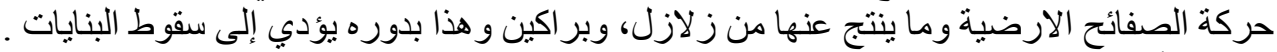

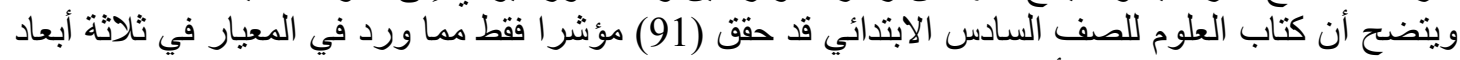

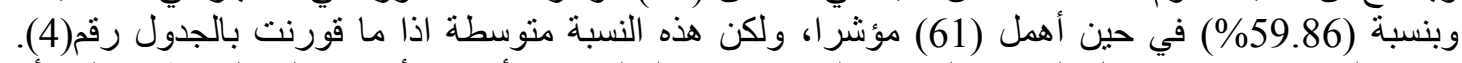

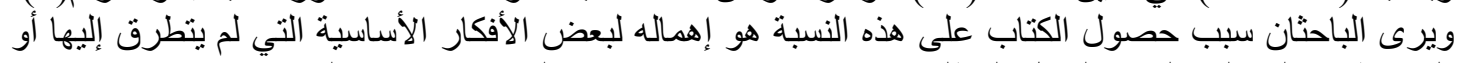

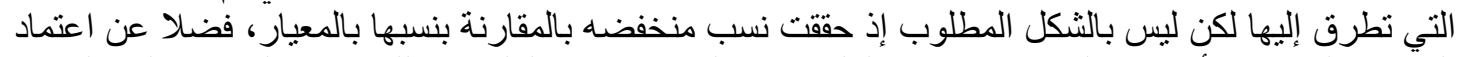

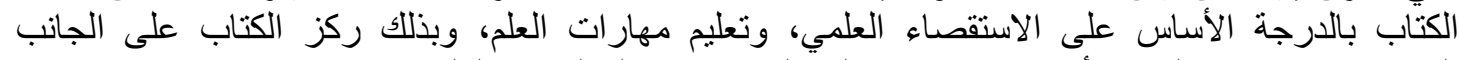

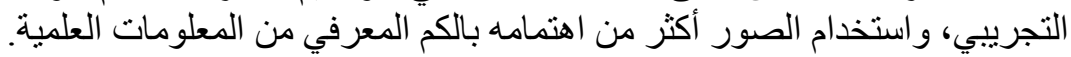

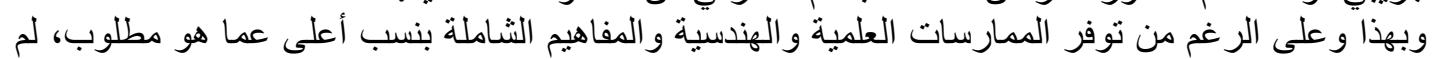

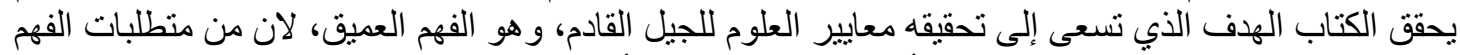

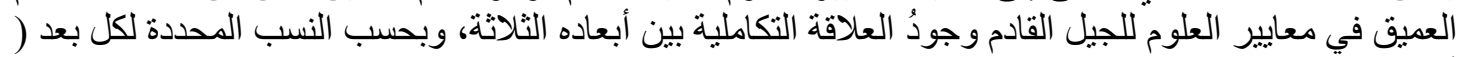

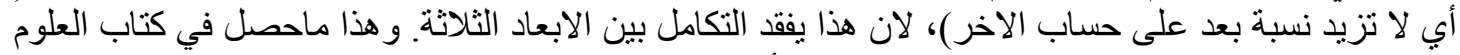

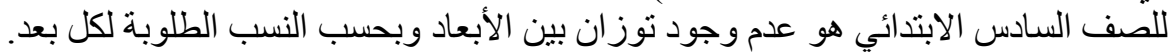

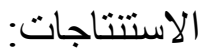
1- كان مستوى تضمين معايير العلوم للجيل القادم في كتاب العلوم للصف السادس الابتدائي متوسطا بالمقارنة بالنسب المحكية المئوية المعتمدة. 2- في كتاب العلوم للصف السادس الابتدائي كان بعد الأفكار الأساسية أقل الأبعاد تضميناً.

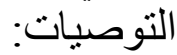
يوصي الباحثنان 1 - باعتماد معايير العلوم للجيل القادم NGSS بتحليل كتب العلوم للمرحلة الابتدائية. 2- اعداد بر امج تدريبية للعملين قائمة على معايير العلوم للجيل القادم NGSS.

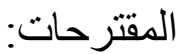

1- - تحليل كتب العلوم للمرحلة الابتدائية على وفق معايير العلوم للجيل القادم NGSS.

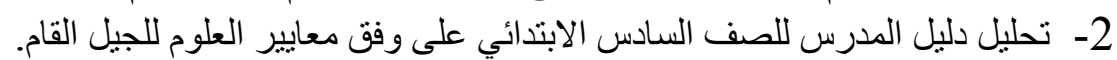

\section{المصادر العربية}

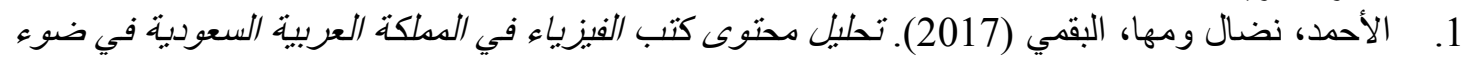

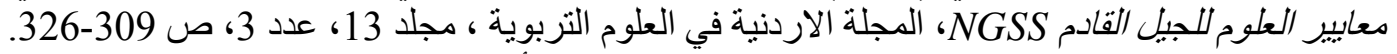
2.

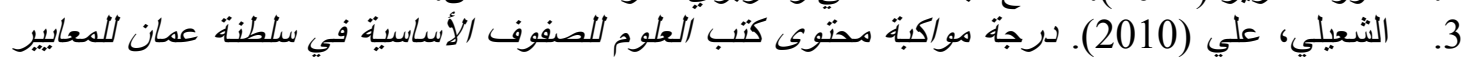

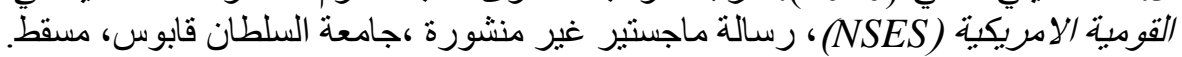

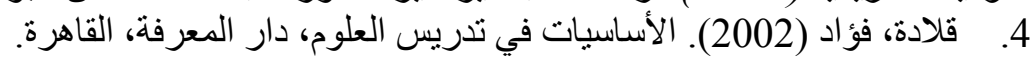

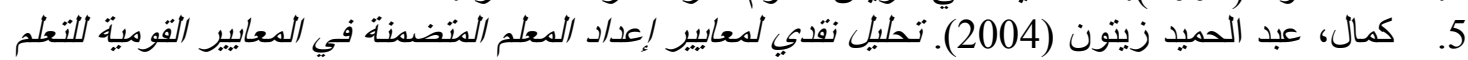

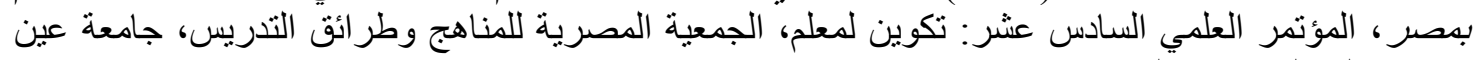

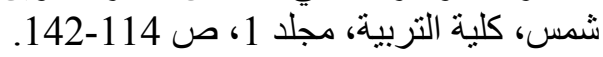

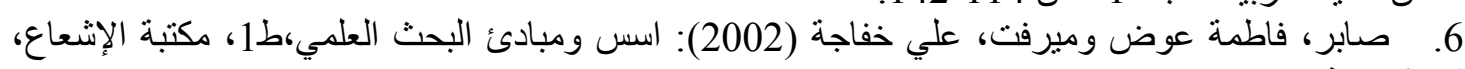
الاسكندرية. 


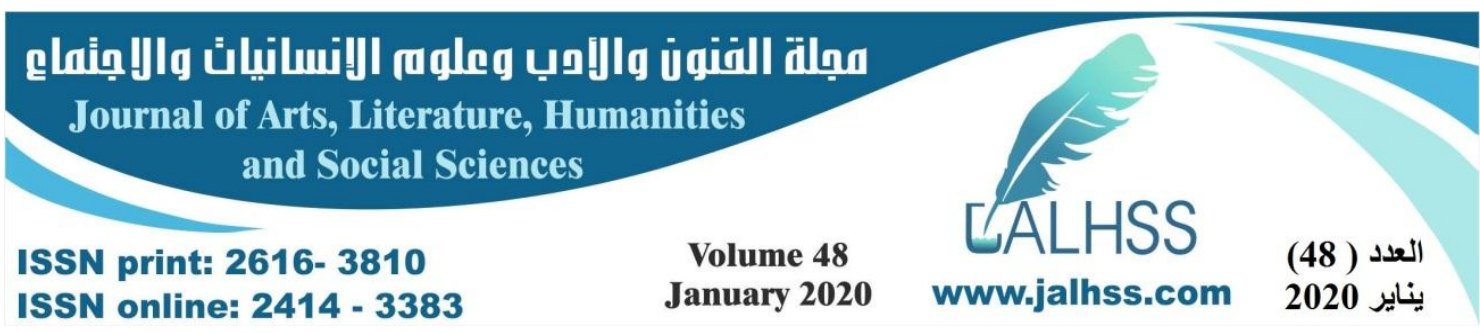

\section{References}

1. Al-Ahmad, Nidal and Maha, Al-Baqmi (2017). An Analysis Of The Content Of Physics Books In The Kingdom Of Saudi Arabia In The Light Of Science Standards For The Next Generation NGSS, The Jordanian Journal of Educational Sciences, Volume 13, Number 3, pp. 309-326.

2. Al-Shuaili, Ali (2010). Degree Of Conformance Of The Content Of Science Books To The Basic Grades In The Sultanate Of Oman With US National Standards (NSES), unpublished Master Thesis, Sultan Qaboos University, Muscat.

3. Dawood, Aziz (2011). Curricula of Scientific and Educational Research, Dar Osama, Amman.

from: http://www.nextgenscience.org/sites/default/files/Appendix

http://www.nextgenscience.org/sites/default/files/Appendix

4. Kamal, Abdel Hamid Zaitoun (2004). A Critical Analysis Of The Teacher Preparation Standards Included In The National Standards For Learning In Egypt, the sixteenth scientific conference: Training for a teacher, the Egyptian Association for Curricula and Teaching Methods, Ain Shams University, College of Education, Volume 1, pp. 114-142.

5. Keltah, Fouad (2002). The Basics in Teaching Science, Dar Al-Maarefa, Cairo.

6. National Research Council (NRC). (2013). Next Generation Science Standards: For States, Washington, DC: The National Academies Press.

7. National Research Council (NRC). (2013). Next Generation Science Standards: For States, Washington, DC: The National Academies Press.

8. National Science Teachers Association (NSTA). (2011). Quality Science Education and $21^{\text {st }}$ Century Skill: http://www.nsta.org/about/positions/21stcentury.aspx.

9. Saber, Fatima Awad and Mervat, Ali Khafaga (2002). The Foundations And Principles Of Scientific Research, $1^{\text {st }}$ edition, Radiation Library, Alexandria.

10. The Next Generation Science Standards (NGSS). (2013), APPENDIX EProgressions Within the Next Generation Science Standards. 1-8. Retrieved December 30, 2016:

11. The Next Generation Science Standards (NGSS). (2013), APPENDIX F- Science and Engineering Practices in the NGSS. 1. 13. Retrieved November 4, from: http://www.Nextgenscience.org/sites/default/files/Appendix\%20F\%20\%20\%Sciencepdf

12. The Next Generation Science Standards(NGSS). (2013), APPENDIX E-Progressions Within the Next Generation Science Standards. 1-8. Retrieved December 30, 2016, from: 13. The Next Generation Science Standards. (2013), Introduction. 1-11. Retrieved January 1, 2017, from:

http://www.nextgenscince.org/sites/default/files/Final\%20Release\%20NGSS\%20From\% 20Matter\%20-\%206.17.13\%20Update-0.pdf

14. The Next Generation Science Standards. (2013), June. The Next Generation Science Standards Executive Summary. 1-3. Retrieved January 1, 2017, from http://www.nextgenscience.org/sites/default/files/Files/\%20Release\%20NGSS\%20Front \%20Matter\%20-\%206.17.13\%20Update0pdf. 


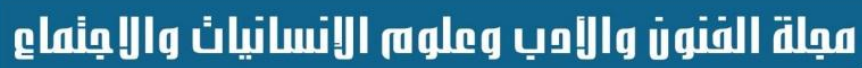

Journal of Arts, Literature, Humanities

and Social Sciences

ISSN print: 2616- 3810

ISSN online: 2414 - 3383
Volume 48

January 2020
¿ALHSS www.jalhss.com
(48) (48)

يناير 2020

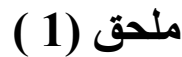

أسماء و عناوين السادة الخبراء والمحكمين ونوع الاستثارة

\begin{tabular}{|c|c|c|c|c|c|c|}
\hline \multicolumn{3}{|c|}{ نوع الاستشـارة } & \multirow[t]{2}{*}{ 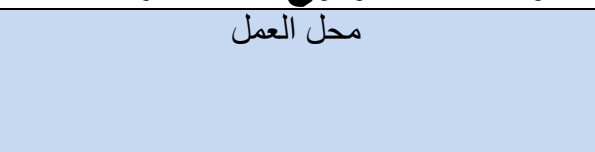 } & \multirow[t]{2}{*}{ الاختصاص } & \multirow[t]{2}{*}{ اسم الخبير والدرجة العلمية } & \multirow[t]{2}{*}{$ت$} \\
\hline 3 & 2 & 1 & & & & \\
\hline & & & جامعة القادسية / كلية التربية/ قسم العلوم & طر ائق تدريس الفيزياء & أ ــ هادي كطفان الثون & 1 \\
\hline & & & جامعة القادسية/كلية التربية/ قسم علوم الحياة & البيئة و التلوث & أ .د فؤاد منحر علكم & 2 \\
\hline & & & جامعة بغداد/ كلية التربية ابن الهيثم/قسم العلوم & ق قياس وتقويم & أ.د احسان عليوي الدليمي & 3 \\
\hline & & & جامعة بغداد / كلية التربية ابن الهيثم / قسم & طر ائق تدريس علوم & أ .د حيدر مسير حمد الله & 4 \\
\hline & & & جامعة بغداد / كلية التربية ابن الهيثم / قسم التربية & طر ائق تدريس علوم & أ أ.د نادية حسين العفون & 5 \\
\hline & & & جامعة القادسية/ كلية التربية/ قسم الفيزياء & & أ.د سليم عزارة & 6 \\
\hline & & & جامعة بغداد/ كلية التربية ابن الهيثم / قسم العلوم & طر ائق تدريس علوم & أ ـد فاطمة عبد الامبر الفتلاوي & 7 \\
\hline & & & جامعة بغداد/ كلية التربية ابن الهيثم/ قسم العلوم & طر ائق تدريس الفيزياء & أ ـد ماجد إبر اهيم الباوي & 8 \\
\hline & & & جامعة الكوفة/ كلية التربية بنات/ قسم العلوم & طر ائق تدريس علوم & أ أ.د عباس عبد المهدي ماضي & 9 \\
\hline & & & جامعة الكوفة/ كلية التربية بنات/ قسم العلوم & طر ائق تدريس علوم & أ ـد قحطان فضل راهي & 10 \\
\hline & & & جامعة القادسية/ كلية التربية/ قسم علوم الحياة & فسلجة حيوان & أ.د حسين الميالي & 11 \\
\hline & & & جامعة القادسية / كلية التربية/ قسم العلوم & طر ائق تدريس علوم & أ .م .د كريم بلاسم خلف & 12 \\
\hline & & & جامعة القادسية/ كلية التربية/ قسم العلوم التربوية & طر ائق تدريس علوم & أ أ.م. د مازن ثامر شنيف & 13 \\
\hline & & & جامعة القادسية/ كلية التربية/ قسم العلوم التربوية & طر ائق تدريس علوم & أ .م .د علي رحيم محمد & 14 \\
\hline & & & جامعة القادسية /كلية التربية/ قسم العلوم التربوية & طر ائق تدريس علوم & أ .م .د إحسان حميد عبد & 15 \\
\hline & & & جامعة القادسية / كلية التربية / قسم العلوم & طر ائق تدريس الفيزياء & أ أ.م. د محسن طاهر مسلم & 16 \\
\hline & & & جامعة القادسية /كلية التربية/ قسم العلوم التربوية & طر ائق تدريس الفيزياء & أ .م .د مهند عبد الحسن رهيو & 17 \\
\hline & & & جامعة بغداد/كلية التربية ابن الهيثم/ قسم العلوم & طر ائق تدريس علوم & أ .م .د أحمد عبيد حسن & 18 \\
\hline & & & جامعة بغداد/ كلية التربية ابن الهيثم/ قسم العلوم & طر ائق تدريس علوم & أ أم ـد نغم هادي عبد الامير & 19 \\
\hline & & & جامعة القادسية/ كلية التربية/ قسم علوم الحياة & البيئة و التلوث & أ أ.م ـد حيد عبد الو احد مالك & 20 \\
\hline
\end{tabular}




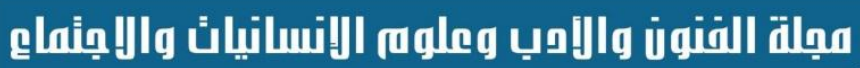

Journal of Arts, Literature, Humanities

and Social Sciences

ISSN print: 2616- 3810

ISSN online: 2414 - 3383

Volume 48 January 2020
LALHSS www.jalhss.com
(48) (48) (48)

يناير

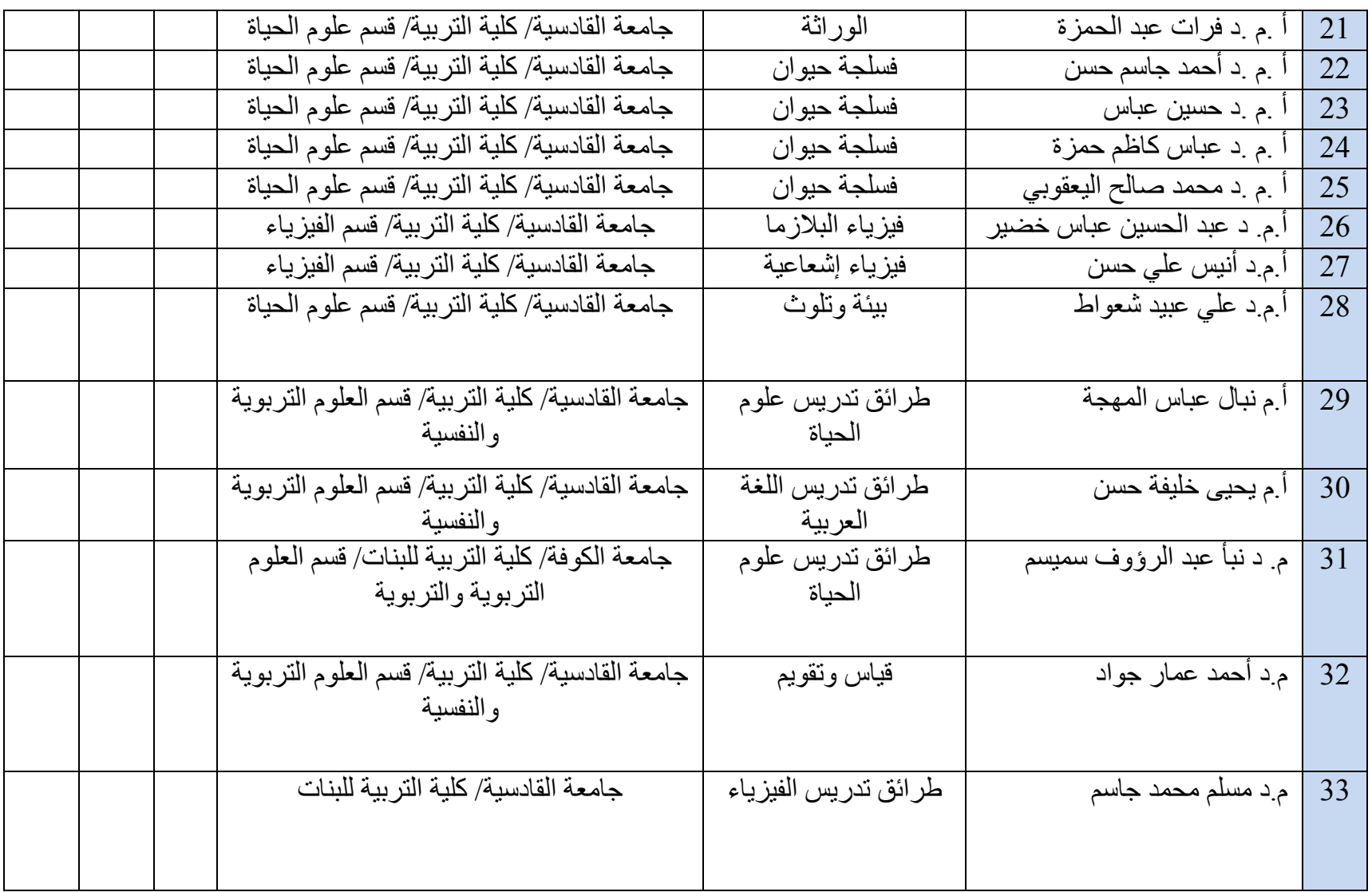

